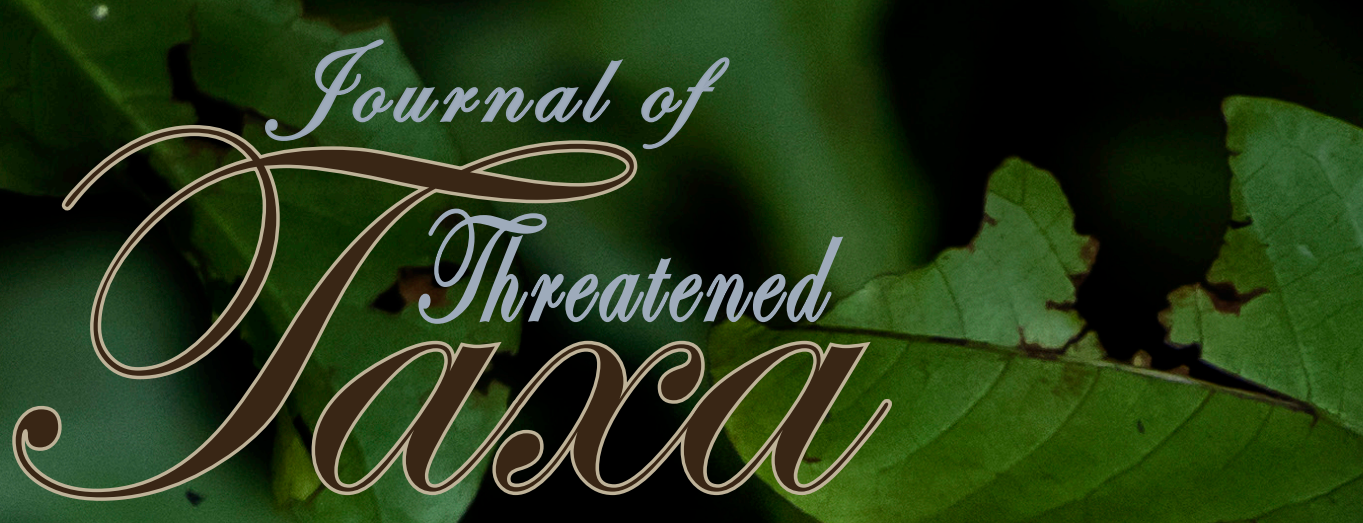

Building exidence for conservation glabally

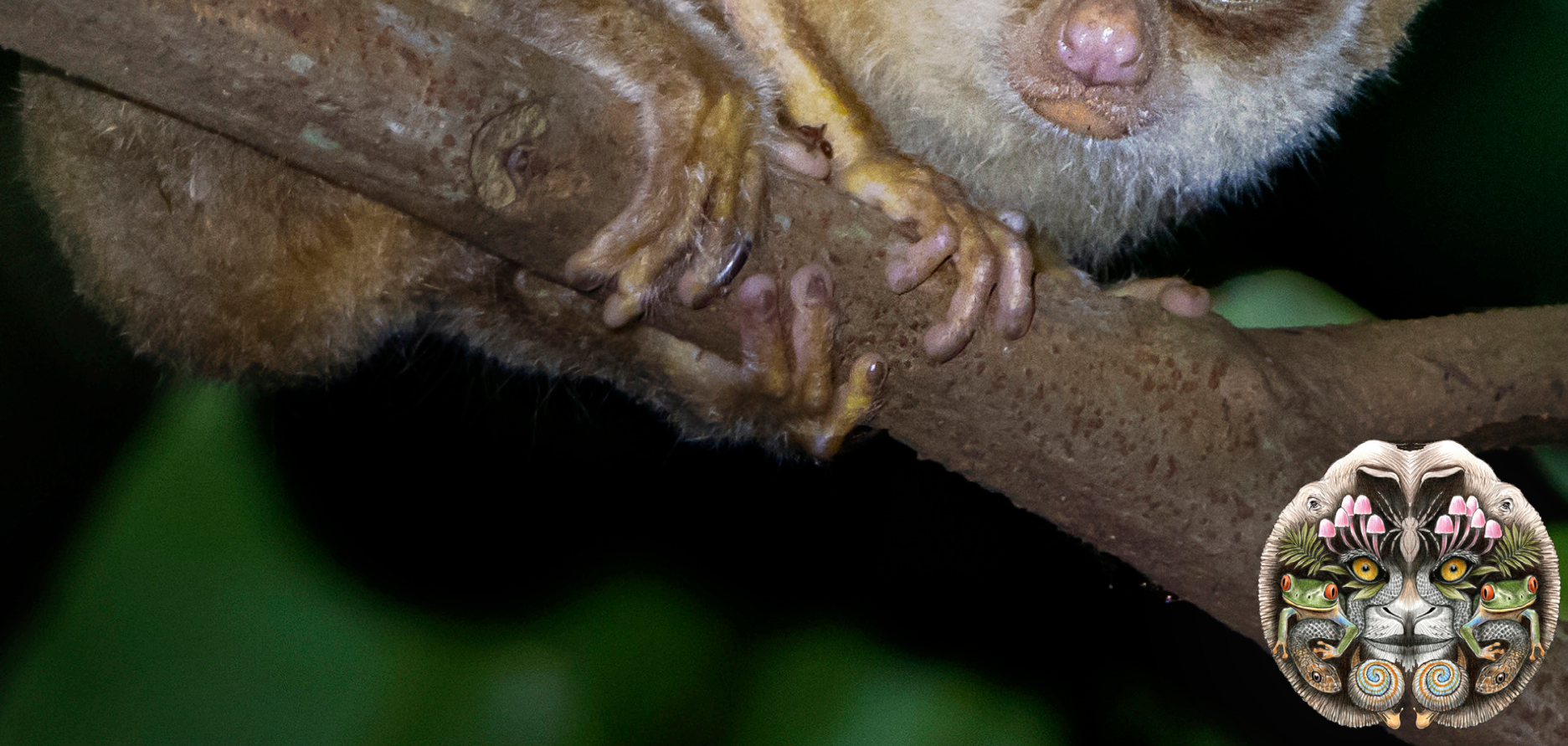

Open Access

$10.11609 /$ jott.2021.13.010.19431-19614 creven.threatenedtaxa.arg

26 September 2021 (Online \& Print) Val. 13 | Na. 11 | Pages: 19431-19674 


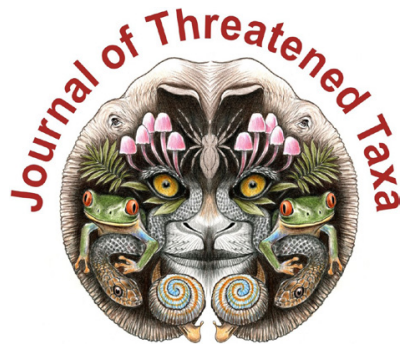

ISSN 0974-7907 (Online); ISSN $0974-7893$ (Print)

Publisher

Host

Wildlife Information Liaison Development Society

www.wild.zooreach.org

Zoo Outreach Organization www.zooreach.org

No. 12, Thiruvannamalai Nagar, Saravanampatti - Kalapatti Road, Saravanampatti, Coimbatore, Tamil Nadu 641035, India

Ph: +91 9385339863 | www.threatenedtaxa.org

Email: sanjay@threatenedtaxa.org

EDITORS

\section{Founder \& Chief Editor}

Dr. Sanjay Molur

Wildlife Information Liaison Development (WILD) Society \& Zoo Outreach Organization (ZOO)

12 Thiruvannamalai Nagar, Saravanampatti, Coimbatore, Tamil Nadu 641035, India

\section{Deputy Chief Edito}

Dr. Neelesh Dahanukar

Noida, Uttar Pradesh, India

\section{Managing Editor}

Mr. B. Ravichandran, WILD/ZOO, Coimbatore, India

\section{Associate Editors}

Dr. Mandar Paingankar, Government Science College Gadchiroli, Maharashtra 442605, India

Dr. Ulrike Streicher, Wildlife Veterinarian, Eugene, Oregon, USA

Ms. Priyanka Iyer, ZOO/WILD, Coimbatore, Tamil Nadu 641035, India

Dr. B. A. Daniel, $200 / \mathrm{WILD}$, Coimbatore, Tamil Nadu 641035, India

\section{Editorial Board}

Dr. Russel Mittermeier

Executive Vice Chair, Conservation International, Arlington, Virginia 22202, USA

\section{Prof. Mewa Singh Ph.D., FASc, FNA, FNASc, FNAPsy}

Ramanna Fellow and Life-Long Distinguished Professor, Biopsychology Laboratory, and Institute of Excellence, University of Mysore, Mysuru, Karnataka 570006, India; Honorary Professor, Jawaharlal Nehru Centre for Advanced Scientific Research, Bangalore; and Adjunct Professor, National Institute of Advanced Studies, Bangalore

\section{Stephen D. Nash}

Scientific Illustrator, Conservation International, Dept. of Anatomical Sciences, Health Sciences Center, T-8, Room 045, Stony Brook University, Stony Brook, NY 11794-8081, USA

\section{Dr. Fred Pluthero}

Toronto, Canada

\section{Dr. Priya Davidar}

Sigur Nature Trust, Chadapatti, Mavinhalla PO, Nilgiris, Tamil Nadu 643223, India

\section{Dr. Martin Fisher}

Senior Associate Professor, Battcock Centre for Experimental Astrophysics, Cavendish

Laboratory, JJ Thomson Avenue, Cambridge CB3 OHE, UK

\section{Dr. John Fellowe}

Honorary Assistant Professor, The Kadoorie Institute, 8/F, T.T. Tsui Building, The University of Hong Kong, Pokfulam Road, Hong Kong

\section{Prof. Dr. Mirco Solé}

Universidade Estadual de Santa Cruz, Departamento de Ciências Biológicas, Vice-coordenado do Programa de Pós-Graduação em Zoologia, Rodovia Ilhéus/Itabuna, Km 16 (45662-000)

Salobrinho, Ilhéus - Bahia - Brasil

\section{Dr. Rajeev Raghavan}

Professor of Taxonomy, Kerala University of Fisheries \& Ocean Studies, Kochi, Kerala, India

\section{English Editors}

Mrs. Mira Bhojwani, Pune, India

Dr. Fred Pluthero, Toronto, Canad

Mr. P. Ilangovan, Chennai, India

Web Maintenance

Mrs. Latha G. Ravikumar, ZOO/WILD, Coimbatore, India

\section{Typesetting}

Mr. Arul Jagadish, ZOO, Coimbatore, India

Mrs. Radhika, ZOO, Coimbatore, India

Mrs. Geetha, ZOO, Coimbatore India

\section{Fundraising/Communications}

Mrs. Payal B. Molur, Coimbatore, India

Subject Editors 2018-2020

Fungi

Dr. B. Shivaraju, Bengaluru, Karnataka, India

Dr. R.K. Verma, Tropical Forest Research Institute, Jabalpur, India

Dr. Vatsavaya S. Raju, Kakatiay University, Warangal, Andhra Pradesh, India

Dr. M. Krishnappa, Jnana Sahyadri, Kuvempu University, Shimoga, Karnataka, India

Dr. K.R. Sridhar, Mangalore University, Mangalagangotri, Mangalore, Karnataka, India

Dr. Gunjan Biswas, Vidyasagar University, Midnapore, West Bengal, India

Plants

Dr. G.P. Sinha, Botanical Survey of India, Allahabad, India

Dr. N.P. Balakrishnan, Ret. Joint Director, BSI, Coimbatore, India

Dr. Shonil Bhagwat, Open University and University of Oxford, UK

Prof. D.J. Bhat, Retd. Professor, Goa University, Goa, India

Dr. Ferdinando Boero, Università del Salento, Lecce, Italy

Dr. Dale R. Calder, Royal Ontaro Museum, Toronto, Ontario, Canada

Dr. Cleofas Cervancia, Univ. of Philippines Los Baños College Laguna, Philippines

Dr. F.B. Vincent Florens, University of Mauritius, Mauritius

Dr. Merlin Franco, Curtin University, Malaysia

Dr. V. Irudayaraj, St. Xavier's College, Palayamkottai, Tamil Nadu, India

Dr. B.S. Kholia, Botanical Survey of India, Gangtok, Sikkim, India

Dr. Pankaj Kumar, Kadoorie Farm and Botanic Garden Corporation, Hong Kong S.A.R., China

Dr. V. Sampath Kumar, Botanical Survey of India, Howrah, West Bengal, India

Dr. A.J. Solomon Raju, Andhra University, Visakhapatnam, India

Dr. Vijayasankar Raman, University of Mississippi, USA

Dr. B. Ravi Prasad Rao, Sri Krishnadevaraya University, Anantpur, India

Dr. K. Ravikumar, FRLHT, Bengaluru, Karnataka, India

Dr. Aparna Watve, Pune, Maharashtra, India

Dr. Qiang Liu, Xishuangbanna Tropical Botanical Garden, Yunnan, China

Dr. Noor Azhar Mohamed Shazili, Universiti Malaysia Terengganu, Kuala Terengganu, Malaysia Dr. M.K. Vasudeva Rao, Shiv Ranjani Housing Society, Pune, Maharashtra, India

Prof. A.J. Solomon Raju, Andhra University, Visakhapatnam, India

Dr. Mandar Datar, Agharkar Research Institute, Pune, Maharashtra, India

Dr. M.K. Janarthanam, Goa University, Goa, India

Dr. K. Karthigeyan, Botanical Survey of India, India

Dr. Errol Vela, University of Montpellier, Montpellier, France

Dr. P. Lakshminarasimhan, Botanical Survey of India, Howrah, India

Dr. Larry R. Noblick, Montgomery Botanical Center, Miami, USA

Dr. K. Haridasan, Pallavur, Palakkad District, Kerala, India

Dr. Analinda Manila-Fajard, University of the Philippines Los Banos, Laguna, Philippines

Dr. P.A. Sinu, Central University of Kerala, Kasaragod, Kerala, India

Dr. Afroz Alam, Banasthali Vidyapith (accredited A grade by NAAC), Rajasthan, India

Dr. K.P. Rajesh, Zamorin's Guruvayurappan College, GA College PO, Kozhikode, Kerala, India

Dr. David E. Boufford, Harvard University Herbaria, Cambridge, MA 02138-2020, USA

Dr. Ritesh Kumar Choudhary, Agharkar Research Institute, Pune, Maharashtra, India

Dr. Navendu Page, Wildlife Institute of India, Chandrabani, Dehradun, Uttarakhand, India

Invertebrates

Dr. R.K. Avasthi, Rohtak University, Haryana, India

Dr. D.B. Bastawade, Maharashtra, India

Dr. Partha Pratim Bhattacharjee, Tripura University, Suryamaninagar, India

Dr. Kailash Chandra, Zoological Survey of India, Jabalpur, Madhya Pradesh, India

Dr. Ansie Dippenaar-Schoeman, University of Pretoria, Queenswood, South Africa

Dr. Rory Dow, National Museum of natural History Naturalis, The Netherlands

Dr. Brian Fisher, California Academy of Sciences, USA

Dr. Richard Gallon, llandudno, North Wales, LL30 1UP

Dr. Hemant V. Ghate, Modern College, Pune, India

Dr. M. Monwar Hossain, Jahangirnagar University, Dhaka, Bangladesh

Mr. Jatishwor Singh Irungbam, Biology Centre CAS, Branišovská, Czech Republic

Dr. lan J. Kitching Natural History Museum, Cromwell Road, UK

Dr. George Mathew, Kerala Forest Research Institute, Peechi, India

Dr. John Noyes, Natural History Museum, London, UK

For Focus, Scope, Aims, and Policies, visit https://threatenedtaxa.org/index.php/JoTT/aims_scope
For Article Submission Guidelines, visit https://threatenedtaxa.org/index.php/JoTT/about/submissions
For Policies against Scientific Misconduct, visit https://threatenedtaxa.org/index.php/JoTT/policies_various 
西

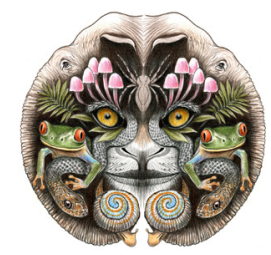

\title{
Understanding human-flying fox interactions in the Agusan Marsh Wildlife Sanctuary as basis for conservation policy interventions
}

\author{
Sherryl L. Paz ${ }^{1}$ (D) \& Juan Carlos T. Gonzalez ${ }^{2}$ (DD \\ ${ }^{1}$ College of Forestry and Environmental Science, Caraga State University, Ampayon, Butuan City, Philippines. \\ ${ }^{2}$ Biological Sciences, University of the Philippines (UPLB), Los Banos, Laguna, Philippines. \\ ${ }^{1}$ sherrylpaz@gmail.com (corresponding author), ${ }^{2}$ jtgonzalez@up.edu.ph
}

\begin{abstract}
There is no documented flying fox hunting study done in the Agusan Marsh Wildlife Sanctuary (AMWS) which is known to harbor many threatened wildlife species. The Large Flying Fox Pteropus vampyrus is known to be threatened by hunting in the AMWS despite existing laws, such as the Wildlife Act. We conducted semi-structured interviews from September 2017 to January 2018 with 240 hunters in 10 villages through purposive sampling to determine the socio-demographic and economic profile of the hunters, their conservation awareness, perceptions on the monitoring scheme and enforcement, possible hunting patterns, and hunting drivers. Results showed that farming and fishing are the most common livelihoods of hunters. Most hunters achieved an education at the elementary level (42.9\%), and belong to a household with 4-6 members (55.5\%), often with only one member having a meager daily income (80.7\%). Annual flooding was the main economic constraint to the hunters. Largely comprised of indigenous Manobos (62.9\%), the majority of hunters did not believe in avoiding taboo species (85.4\%). Most of the hunters were unaware of laws protecting Wildlife (62.9\%) and unable to differentiate between threatened and non-threatened species (86.3\%). Poor implementation of the monitoring scheme and insufficient enforcement were also observed in AMWS. Kites with hooks (55\%) and guns (31.7\%) were used to hunt $P$. vampyrus mostly for local consumption (83.3\%). Multivariate analysis revealed that daily income and engagement in conservation negatively affected hunting intensity. With many constraints in totally banning hunting in poor and wildlife-dependent indigenous communities in AMWS, flexible policies must be considered. It is more reasonable and realistic to consider science-based hunting quotas in policy interventions to balance conservation and human welfare. Positive behavioral change towards sustainable hunting and trading bans requires a combination of effective education campaigns, engagement of indigenous communities in conservation, improved enforcement, and sustainable livelihood programs.
\end{abstract}

Keywords: Hunting, indigenous people, Manobo, Pteropus vampyrus, protected area, subsistence, threatened.

Citation: Sherryl L. Paz \& Juan Carlos T. Gonzalez (2021). Understanding human-flying fox interactions in the Agusan Marsh Wildlife Sanctuary as basis for conservation policy interventions. Journal of Threatened Taxa 13(11): 19431-19447. https://doi.org/10.11609/jott.7466.13.11.19431-19447

Copyright: (C) Paz \& Gonzalez 2021. Creative Commons Attribution 4.0 International License. JoTT allows unrestricted use, reproduction, and distribution of this article in any medium by providing adequate credit to the author(s) and the source of publication.

Funding: DOST-ASTHRDP Student Research Support Fund.

Competing interests: The authors declare no competing interests.

Author details, Author contributions and Tagalog abstract: See end of this article.

Acknowledgements: We express our gratitude to the DOST-ASTHRDP Student Research Support Fund for the financial resources to do the surveys and Idea Wild for providing some of the needed documentation equipment. We also thank the tribal chieftains and the local government officials who without hesitation allowed me to conduct the sampling activities in their respective areas. We were also grateful for the support of AMWS-PAMB and PASu in the conduct of this research. Most of all, we highly appreciated the contribution of the mentors and the advisory committee of Sherryl L. Paz as this paper is part of her PhD dissertation.
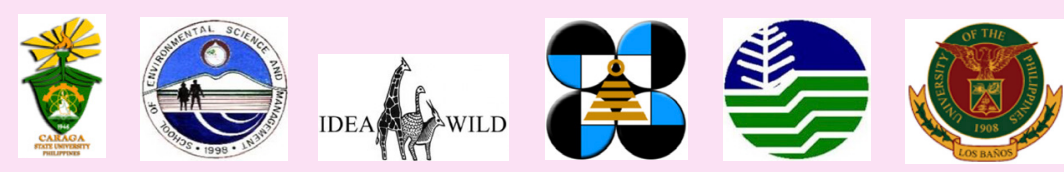


\section{INTRODUCTION}

The Philippines is a megadiverse country, recognized for its exceptional richness and endemism of wildlife (Myers et al. 2000; Posa et al. 2008). However, the country is facing rapid forest loss (WRI 2003; Apan et al. 2017) and is known to be a biodiversity hotspot (Myers et al. 2000; Gonzalez et al. 2018). To conserve and protect a high number of threatened species, a network of protected areas was established (Mallari et al. 2016). The Giant or Large Flying Fox Pteropus vampyrus Linnaeus, 1758 is a threatened wildlife species found in the Philippines, which also occurs in other southeastern Asian countries (Bates et al. 2008). Like other flying foxes, it plays a very important role in seed dispersal, pollination, and forest regeneration (Corlett 1998; Kunz \& Jones 2000; McKonkey et al. 2006; Nakamoto et al. 2008; Shilton \& Whittaker 2009; Aziz et al. 2021). It is currently listed as 'Near Threatened' by the International Union for the Conservation of Nature (IUCN 2021) but is locally listed as Endangered in the Department of Environment and Natural Resources Administrative Order (DAO 2019-09) due to intense hunting pressure, continuous roost disturbance, and reduction of its lowland forest habitat (Bates et al. 2008; Gonzalez et al. 2018). Pteropus vampyrus is listed under Appendix II of the Convention on International Trade in Endangered Species of Wild Fauna and Flora (CITES) and occupies broad trans-national home ranges (Epstein et al. 2009).

Half of all extant large-bodied species in the genus, Pteropus are unsustainably hunted across Indonesia, Malaysia, the Philippines, and several islands in the Pacific and Indian Oceans (Mickleburgh et al. 2009; Wiles \& Brooke 2009; IUCN 2014). Increasing flying fox hunting pressure in North Sulawesi for example is brought about by intense trading and consumption (Sheherazadee \& Tsang 2015). This is of major conservation concern because flying foxes are vulnerable to overhunting due to their slow rate of reproduction (Mildenstein et al. 2016), long gestation, and slow fetal growth (Racey \& Entwistle 2000; Mcllwee \& Martin 2002). Hence, the survival of many chiroterophillic plant species that rely on bats particularly flying foxes for pollination and seed dispersal will be adversely affected by the decrease in their abundance and diversity (Claytn \& MilnerGulland 2000). Decreasing population of flying foxes has economic impacts which may directly affect local communities, e.g., farmers who are dependent on batpollinated fruit crops (Aziz et al. 2021).

There are still cases of hunting and trade even within protected areas, e.g., flying fox trading from protected areas on Sulawesi which are supposed to protect natural habitats and animal populations (Lee at al. 2005; Worboys \& Winkler 2006). Despite the enactment of the Wildlife Resources Conservation and Protection Act (Wildlife Act, RA No. 9147), the hunting of flying foxes is still prevalent in several protected areas of the Philippines such as in the Mountain Ranges of the Sierra Madre (Scheffers et al. 2012), Mt. Apo National Park (Tanalgo 2017), and in the Agusan Marsh Wildlife Sanctuary (AMWS).

Agusan Marsh is one of the most ecologically significant wetlands in the Philippines and is one of Asia's most important transit points for migratory birds. Freshwater swamp forests comprise $49 \%$ of the total area in AMWS. Three major forest types were identified, namely, mixed swamp forests, peat swamp forests or pygmy forests, and the inundated lowland evergreen forest. There were 25 threatened species recorded, of which $84 \%$ are endemic to the country such as the threatened flying foxes, e.g., the Endangered Giant Golden-crowned Flying Fox Acerodon jubatus and the Near Threatened Giant or Large Flying Fox under IUCN which are already Critically Endangered and Endangered respectively under DAO 2019-09 (Department of Environment and Natural Resources-Caraga 2015).

Both indigenous and non-indigenous people inhabiting the sanctuary were reported to hunt $P$. vampyrus for local consumption and local trading. Hunting is the greatest threat to Philippine bats particularly the frugivorous species such as flying foxes (Tanalgo \& Hughes 2019). However, there is no known quantitative research conducted on flying foxes within the AMWS (Tanalgo \& Hughes 2018).

Regulation of $P$. vampyrus hunting requires baseline information on hunting patterns and its potential drivers. The findings of hunting research in AMWS will inform adaptive wildlife conservation programs, policy interventions, resource prioritization, and a more effective protected area management (Friant et al. 2015). Understanding human-flying fox interaction is essential to effective long-term conservation, efficient law enforcement, and persistence of the flying fox population. In this paper, we show the demographic, socio-economic, and cultural profile of the hunters, their level of conservation awareness, and perceptions. Here, we also present $P$. vampyrus hunting patterns, the frequency and number of individuals hunted across different periods and the main drivers of Giant or Large flying fox hunting within AMWS. All this information is important to design an adaptive flying fox conservation 
program in AMWS and other protected areas.

\section{METHODS}

\section{A. Study Site and Focal Species}

A series of surveys were conducted within Agusan Marsh Wildlife Sanctuary located at $8.316 \mathrm{~N}$ and 125.866E covering eight municipalities in the province of Agusan del Sur, Mindanao Island (Figure 1 \& Image S2). Agusan Marsh is the catchment basin for tributaries flowing from surrounding areas of Compostela Valley, Agusan del Norte and Agusan del Sur, and Bukidnon provinces. AMWS has an area of 19,196 ha which was proclaimed a protected area under RA No. 7586 or the National Integrated Protected Areas System (NIPAS) Act under Presidential Proclamation 913 dated 31 October 1996 (Department of Environment and Natural Resources (DENR-Caraga 2015). In 1999, the AMWS was designated as a Wetland of International Importance by the Ramsar Convention (Primavera \& Tumanda 2007).

The Manobos represent the most dominant $(70 \%$ of the population) indigenous group among the five identified tribes within the protected area, including the Kamayo, Higaonon, Banwaon, and Talaandig (Bendsen et al. 2017). Four Certified Ancestral Domain Titles (CADT) cover $55 \%$ of this area and one other claim is currently being processed (Bendzen et al. 2017). The biological diversity within the AMWS is being threatened by illegal destructive practices including hunting and trapping of wildlife species (PEF et al. 2008).

The Large Flying Fox is one of the world's largest bats (Stier \& Mildenstein 2005). It is one of the largest flying foxes (11 species) out of the total 27 species of the Old World fruit bats (Order Chiroptera, Family Pteropodidae) recorded in the Philippines (Heaney et al. 1998; Tanalgo $\&$ Hughes 2018). By contrast, the endemic Giant Goldencrowned Flying Fox is the world's heaviest bat at up to $1.4 \mathrm{~kg}$. Similar in size and weight, both have completely blackish-brown fur on the upper back. The Common Island Flying Fox Pteropus hypomelanus Temminck, 1853 is similar in appearance to the Giant Flying Fox but smaller in size and weight with a golden dorsal pelage that is never completely black on the upper back. It occurs from Thailand to Australia, and throughout the Philippines (Ingle \& Heaney 1992; Heaney et al. 1998). Of the 13 species of bats recorded within AMWS, including nine fruit bats, $P$. hypomelanus has not been observed in AMWS (Ibanez \& Bastian 2015).

Pteropus vampyrus roosts in the top of large trees, with single colonies numbering from 12 to
100,000 individuals often forming mixed roosts with $A$. jubatus. Populations of both flying foxes have declined dramatically in the last century, principally due to the loss of their natural forest habitats. To distinguish the two species in mixed roosts, the dorsal pelage of $P$. vampyrus is usually blackish-brown and golden on the upper back, with the posterior margin sharply defined by a dark brown transverse line on the lower back, that ends in a narrow "V" at the nape and shoulders (Image S2). The ear tips are nearly pointed. In contrast, the dorsal pelage of $A$. jubatus is not completely blackish-brown, and has a golden patch on top of the head extending to the ears, but lacks the dark brown transverse line on the lower back. The ear tips are bluntly rounded. P. vampyrus is widely distributed from Indochina to the Lesser Sundas, while $A$. jubatus is endemic only to the Philippines (Ingle \& Heaney 1992; Heaney et al. 1998).

\section{B. Study Design, Questionnaire and Ethical Note}

After securing the AMWS Protected Area Management Board (PAMB) and free prior and informed consent (FPIC) approval (signed by the tribal leaders), a purposive sampling was done in the identification of $P$. vampyrus hunting "hotspots" (barangays and municipalities where illegal hunting was most prevalent) with the help of key informants such as the protected area superintendent, and local government officials. Snowballing was also used to identify hunters where the preceding hunter-interviewees provided contacts to be included in the succeeding interviews. The first draft of the questionnaire was tested with 30 respondents in one of the identified hunting hotspots (not subsequently included during actual surveys) for questionnaire validation in September 2017. Feedbacks from the respondents on the construction of questions (degree of comprehensibility, flow of questions, length of questionnaire, and level of sensitivity) served as the basis for questionnaire revisions. Actual interviews with a total of 240 hunters (face-to-face semi-structured interviews in Cebuano dialect) were carried out in six municipalities within AMWS including San Francisco $(33.3 \%, n=80)$, Loreto $(13.3 \%, n=32)$, La Paz $(17.1 \%, n=$ 41), Talacogon $(9.6 \%, n=23)$, Bunawan $(12.9 \%, n=31)$, and Rosario (13.8\%, n= 33) from October 2017 to January 2018. The head of the household was the main target of the interview. Alternatively, if the head of the household was already deceased, the eldest male child who also participated in hunting was instead interviewed.

In the first part of the questionnaire, we asked about the socio-demographic and economic information such as age, the number of family members, ethnicity, length 


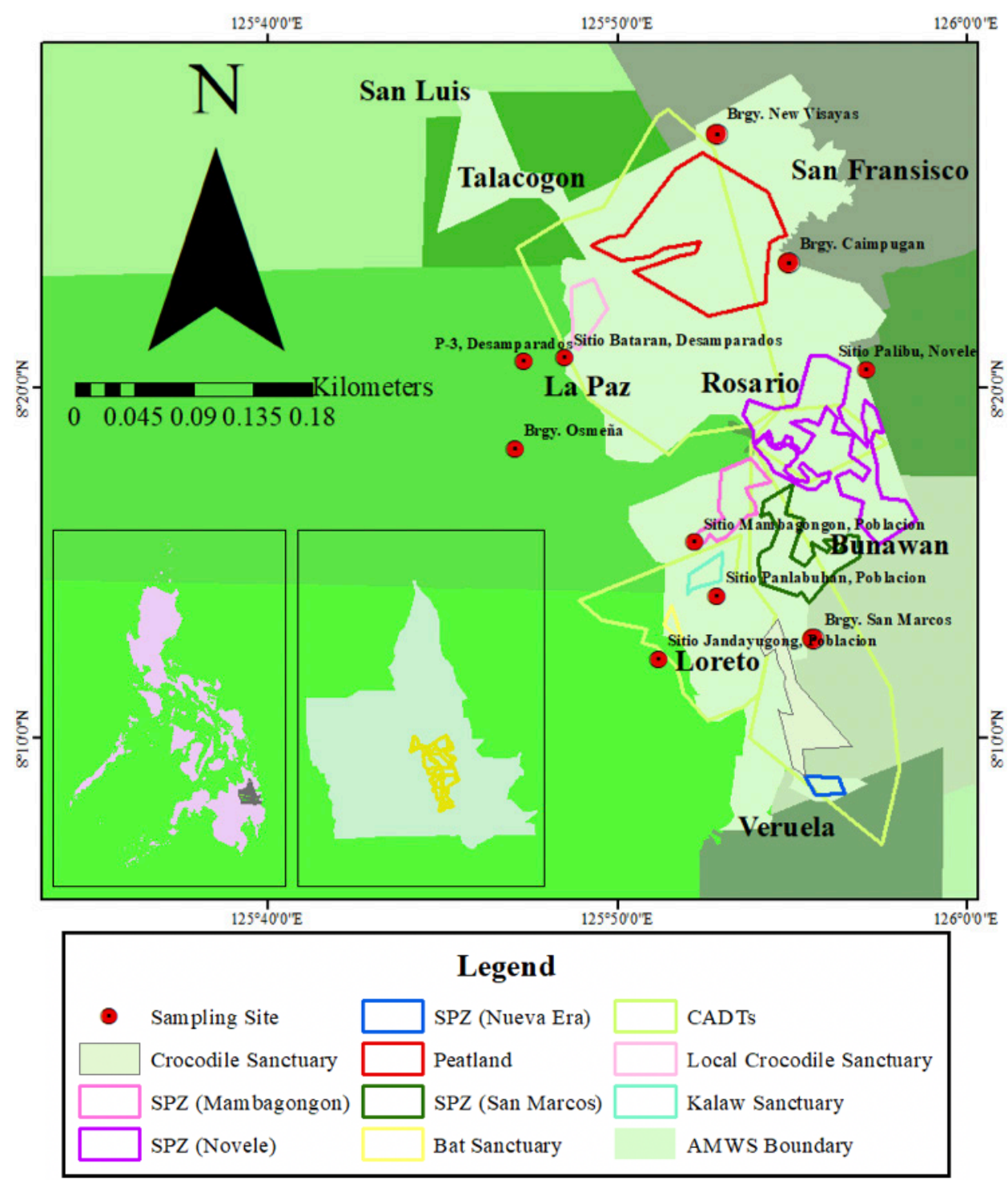

Figure 1. Map showing sampling sites within and the surroundings of Agusan Marsh Wildlife Sanctuary (AMWS) including the municipalities, special protection zones and the major zones.

of residency, and educational attainment (Appendix 1). Socio-economic data were also gathered, such as the main source of livelihood, supplementary livelihood, average daily income incurred during the dry and wet seasons, number of family members with income, and constraints to economic opportunities. We also asked for cultural information in the second part of the questionnaire such as the hunter's beliefs on 'speciesspecific taboos' and traditional cultural practices related to hunting.

In the third part of the questionnaire, we asked questions about the awareness and perceptions of the hunters such as their awareness of conservationrelated activities ( 1 - no; 2 - yes), Wildlife Act ( 1 - not totally aware of the law, and its content; 2 - aware of the law but do not fully understand the content and its implication to wildlife conservation; 3 - fully aware of the law and understand its content and conservation implication) and recognition and differentiation of threatened and non-threatened species (picture cards were shown and the concept of 'threatened species' were explained first to the respondents using their dialect before asking this question). Hunter's attendance to information, education, and communication campaigns (IEC) explaining the ecological services provided by flying foxes were also assessed ( 1 - did not attend any IEC on flying foxes; 2 - was able to attend but IEC did not include the ecological services provided by flying foxes; 3 - was able to attend and the IEC included the ecological services and importance of flying foxes). This 
information is essential to inform adaptive and effective awareness and outreach campaigns.

We also asked about hunters' engagement in conservation-related activities, e.g., reforestation, conservation of flying fox, and other wildlife (1 no; 2 - yes). Information on patrolling schemes and law enforcement is quite useful as a basis for designing a sustainable flying fox protection plan without compromising the welfare of the indigenous communities. Hence, the frequency of monitoring, hunting, and trade by the local forest wardens, and the patrolling frequency by the DENR enforcers at AMWS were also determined as perceived by the hunters (1 never; 2 - hardly ever or <once a month; 3 - regularly or more than once a month; 4 - frequently or more than once a week). The extent of Wildlife Act enforcement was also investigated such as the number of violators fined, convicted, or jailed (anyone that they know in the community). The willingness of hunters to regulate hunting and minimize consumption of $P$. vampyrus was also assessed.

Quantitative assessment of hunting patterns was also carried out through direct interviews. Picture cards of bats were shown to each respondent to confirm the identity of the species hunted, and their motivation for hunting flying foxes was recorded. The most used hunting places within AMWS were identified and distance from the hunter's dwelling in kilometers was estimated. Moreover, hunting techniques used were also described and documented. The estimated hunting frequency (number of times a hunter hunts per time period) and hunting success (number of individuals hunted per time period) were investigated across different periods (conducted a month before the interview - 2017, also in 2016, and in 2012 with data spanning five years).

Descriptive statistical analysis in Paleontological Statistics or PAST (Hammer et al. 2001) was done for the demographic and socio-economic characteristics of the hunters and their hunting pattern responses. MannWhitney $U$ test was performed to test if there was a significant difference between the hunting frequency and hunting success recorded between 2016 and 2012 at p value $=0.05$ (per year basis). Multiple regression analysis in SPSS was used to determine the factors that influence hunting frequency and hunting success (number of bats taken in 2016). Numerical predictor variables included the hunter's age and length of residency at AMWS (in years), average daily income in Philippine peso (PHP), distance to the hunting zone from the hunter's dwelling (in kilometers), and allocated time for hunting time (in hours). Categorical predictor variables used were the hunter's educational attainment, engagement in any conservation-related activities, attendance to IEC, and awareness of conservation-related activities conducted within AMWS. The dependent and independent variables were subjected to diagnostic tests to check the normality of the residuals. Pearson's correlation analysis was conducted before running the regression models to avoid multicollinearity among independent variables. All reported statistical tests were conducted at a $95 \%$ confidence level.

\section{RESULTS}

\section{Demographic and Socio-economic Profile of Hunters}

All the respondents engaged in hunting $P$. vampyrus $(n=240)$ within AMWS were males. Nearly $75 \%(n=174)$ of the hunters were between $21-50$ years old (Table 1 ). Most of the hunters have a family size of 4-6 members (55.5\%, $n=132$ ). More than half of the hunters were comprised of the 'Manobo' ethnic group (62.9\%, $n=$ $151)$, followed by migrant ethnolinguistic groups, Bisaya $(18.5 \%, n=44)$, and Hilonggos $(17.6 \%, n=42)$. Half of the hunters $(50 \%, n=121)$ lived in their respective villages for $21-40$ years. A good number of hunters $(42.9 \%, n=$ 102) graduated with elementary education, followed by high school undergraduates $(23.1 \%, n=76)$ which formed nearly a quarter of the total. Only a few were considered illiterate $(1.7 \%, n=4)$ and there was a very low percentage of those who finished college $(3.3 \%, n=8)$.

Most of the hunters engaged in rice farming during the dry season $(60 \%, n=144)$, and some of them did fishing during the wet season $(35.4 \%, n=85$ ) (Table S1). Most of the hunters considered flood $(87.9 \%, n=$ 211) as a key constraint to economic opportunities and agricultural productivity followed by bad roads (38.8\%, $n=93 \%)$ and drought $(25.8 \%, n=62)$.

Most of the hunters $(80.7 \%, n=192)$ mentioned that there is only one family member with income. We also found that more than half of the hunters had no supplementary source of income during the dry season $(51.3 \%, n=123)$ and there were even more of those who do not have any supplementary income source during the wet season $(66.7 \%, n=160$ ) (Table 2 ).

The $42.1 \%(n=101)$ of the flying fox hunters have an estimated daily income of Php 101-200 (42.1\%, $n=101)$. The average daily income earned during the dry season (Php 182.50) was found to be significantly higher than during the wet season (Php 123.63) ( $p<0.001)$.

More than half of the hunters interviewed were ethnic 'Manobos' (62.9\%). Most of them (85.42\%, $n=$ 
Table 1. Demographic Characteristics of the $P$. vampyrus hunters in Agusan Marsh Wildlife Sanctuary $(n=240)$.

\begin{tabular}{|c|c|c|}
\hline & Frequency & Percentage (\%) \\
\hline \multicolumn{3}{|l|}{ Age (years) } \\
\hline $11-20$ & 5 & 2.1 \\
\hline $21-30$ & 60 & 25.0 \\
\hline $31-40$ & 57 & 23.8 \\
\hline $41-50$ & 57 & 23.8 \\
\hline $51-60$ & 39 & 16.3 \\
\hline $61-70$ & 17 & 7.1 \\
\hline $71-80$ & 5 & 2.1 \\
\hline \multicolumn{3}{|l|}{$\begin{array}{l}\text { Number of Family } \\
\text { Members }\end{array}$} \\
\hline $1-3$ & 63 & 26.5 \\
\hline $4-6$ & 132 & 55.5 \\
\hline $7-9$ & 37 & 15.5 \\
\hline $10-12$ & 7 & 2.9 \\
\hline $13-15$ & 1 & 0.42 \\
\hline \multicolumn{3}{|l|}{ Ethnicity } \\
\hline Bisaya & 44 & 18.5 \\
\hline Butuanon & 1 & 0.42 \\
\hline Hilonggo & 42 & 17.6 \\
\hline Ilocano & 21 & 0.84 \\
\hline Manobo & 151 & 62.9 \\
\hline \multicolumn{3}{|l|}{$\begin{array}{l}\text { Length of } \\
\text { Residency }\end{array}$} \\
\hline $1-10$ & 23 & 9.7 \\
\hline $11-20$ & 17 & 7.1 \\
\hline $21-30$ & 76 & 31.9 \\
\hline $31-40$ & 45 & 18.9 \\
\hline $41-50$ & 43 & 18.1 \\
\hline $51-60$ & 20 & 8.4 \\
\hline $61-70$ & 12 & 5 \\
\hline $71-80$ & 3 & 1.3 \\
\hline $81-90$ & 1 & 0.42 \\
\hline \multicolumn{3}{|l|}{$\begin{array}{l}\text { Educational } \\
\text { Attainment }\end{array}$} \\
\hline None (illiterate) & 4 & 1.7 \\
\hline $\begin{array}{l}\text { Elementary } \\
\text { undergraduate }\end{array}$ & 8 & 3.4 \\
\hline $\begin{array}{l}\text { Elementary } \\
\text { graduate }\end{array}$ & 102 & 42.9 \\
\hline $\begin{array}{l}\text { Highschool } \\
\text { undergraduate }\end{array}$ & 55 & 23.1 \\
\hline $\begin{array}{l}\text { Highschool } \\
\text { graduate }\end{array}$ & 29 & 12.2 \\
\hline $\begin{array}{l}\text { College } \\
\text { undergraduate }\end{array}$ & 34 & 14.3 \\
\hline College graduate & 8 & 3.3 \\
\hline
\end{tabular}

Table 2. Socio-economic Profile of $P$. vampyrus hunters (number of supplementary income sources and estimated daily income in peso (PHP) during the dry and wet season in Agusan Marsh Wildlife Sanctuary

\begin{tabular}{|c|c|c|c|}
\hline & $\begin{array}{c}\text { Wet Season } \\
(\%, \mathrm{n})\end{array}$ & Dry Season (\%,n) & $\begin{array}{c}\text { Overall } \\
(\%, \mathrm{n})\end{array}$ \\
\hline $\begin{array}{c}\text { Number of supplementary } \\
\text { income sources }\end{array}$ \\
\hline 0 & $66.7 \%(160)$ & $51.3 \%(123)$ & $59.1 \%(142)$ \\
\hline 1 & $24.20 \%(58)$ & $27.9 \%(67)$ & $26.3 \%(63)$ \\
\hline 2 & $7.5 \%(18)$ & $7.9 \%(19)$ & $7.9 \%(19)$ \\
\hline 3 & $1.7 \%(4)$ & $2.9 \%(7)$ & $2.5 \%(6)$ \\
\hline Estimated daily income in peso (PHP) & 0 \\
\hline 0 & $10.3 \%(25)$ & $8.3 \%(20)$ & $39.2 \%(94)$ \\
\hline $50-100$ & $44.2 \%(106)$ & $31.7 \%(76)$ & $42.1 \%(19)$ \\
\hline $101-200$ & $23.3 \%(56)$ & $40 \%(96)$ & $18.3 \%(44)$ \\
\hline $201-300$ & $13.8 \%(33)$ & $23.8 \%(57$ & 0 \\
\hline $301-400$ & 0 & $3.3 \%(8)$ & \\
\hline
\end{tabular}

Table 3. Awareness of $P$. vampyrus hunters in Identifying and Differentiating Threatened and Non-threatened Flying Fox Species, Wildlife Act (RA 9147) and their attendance to Information, Education and Communication Campaign on Flying Fox Conservation in Agusan Marsh Wildlife Sanctuary.

\begin{tabular}{|c|c|c|}
\hline & $f$ & $\%$ \\
\hline \multicolumn{3}{|l|}{$\begin{array}{l}\text { Knowledge on identifying and differentiating } \\
\text { threatened and non-threatened flying fox species }\end{array}$} \\
\hline No & 207 & 86.3 \\
\hline Slightly Yes & 31 & 12.9 \\
\hline Definitely Yes & 2 & 0.83 \\
\hline \multicolumn{3}{|l|}{ Awareness of Wildlife Act (RA 9147) } \\
\hline No & 151 & 62.9 \\
\hline Slightly Yes & 60 & 25 \\
\hline Definitely Yes & 29 & 12.1 \\
\hline \multicolumn{3}{|l|}{$\begin{array}{l}\text { Attendance to Information, Education and } \\
\text { Communication Campaign on flying fox conservation }\end{array}$} \\
\hline $\begin{array}{l}\text { Never (Did not attend any IEC on flying fox } \\
\text { conservation) }\end{array}$ & 180 & 75 \\
\hline $\begin{array}{l}\text { Slightly Yes (Attended but IEC did not include the } \\
\text { ecological services provided by flying foxes) }\end{array}$ & 28 & 11.7 \\
\hline $\begin{array}{l}\text { Definitely Yes (Attended the IEC including the } \\
\text { ecological services and importance of flying foxes) }\end{array}$ & 32 & 13.3 \\
\hline
\end{tabular}

205) did not believe in the practice of species-specific taboos (avoidance of wildlife as food or cultural taboos on hunting and killing certain species). Only eight of the respondents $(3.3 \% . \mathrm{n}=8)$ mentioned that $P$. vampyrus and other flying foxes were recognized as taboo species (flying foxes are considered as sacred and can most likely cause misfortune or death when they are killed and eaten). 


\section{Awareness and Perceptions of Hunters}

Most of the hunters $(89.58 \%, n=215)$ were not engaged in any conservation-related activities in their respective villages although, most of the hunters $(87.5 \%$, $\mathrm{n}=210$ ) mentioned that they were aware of the existing conservation-related activities implemented in AMWS such as reforestation projects, field research conducted by students and visiting scientists as well as the patrolling of the lake and swamp forest by forest wardens.

More than half of the hunters $(62.9 \%, n=151)$ were totally unaware of the Wildlife Act and its content, while $25 \%(n=60)$ were aware of this law, but did not fully understand its content and its implication to wildlife conservation (Table 3 ). A large proportion of hunters $(86.3 \%, n=207)$ reported that they were unable to identify and differentiate threatened from nonthreatened species of flying foxes. Three-quarters of the hunters in AMWS $(75 \%, n=180)$ were not able to attend any flying fox conservation-focused information education and communication (IEC) campaign in their village. However, some 28 hunters (11.7\%) mentioned that they were able to attend IEC campaigns conducted in their village (mostly by DENR personnel and some by NGOs), but the ecological services provided by flying foxes were not given emphasis.

Half of the respondents $(50 \%, n=120)$ mentioned that local forest and lake wardens within AMWS rarely (less than once a month) performed their duties in patrolling known hunting areas for illegal poachers and detect trading of wildlife products $(49.6 \%, n=$ 119) (Figure 2). Moreover, many hunters $(74.2 \%, n=$ 178) also observed that government employees duly assigned as enforcers hardly ever visited the hunting areas. In terms of enforcement, no $P$. vampyrus hunter has been fined, convicted, or jailed within AMWS during the period $2017-2018$ as mentioned by $100 \%$ of the hunters. Nevertheless, most of the hunters expressed

Table 4. Willingness of the flying fox hunters to regulate hunting and consumption in Agusan Marsh Wildlife Sanctuary.

\begin{tabular}{|c|c|c|}
\hline & $f$ & $\%$ \\
\hline \multicolumn{3}{|c|}{ Willingness to regulate flying fox hunting } \\
\hline No & 35 & 14.6 \\
\hline Slightly Yes & 39 & 16.3 \\
\hline Definitely Yes & 166 & 69.2 \\
\hline \multicolumn{3}{|c|}{ Willingness to regulate consumption of flying fox } \\
\hline No & 20 & 8.3 \\
\hline Slightly Yes & 11 & 4.6 \\
\hline Definitely Yes & 209 & 87.1 \\
\hline
\end{tabular}

high willingness to regulate the hunting of $P$. vampyrus in AMWS $(69.2 \%, n=166)$ and to effectively regulate the consumption of Large Flying Foxes in the area $(87.1 \%, n=$ 208) (Table 4).

\section{Hunting Patterns of Large Flying Foxes}

Results showed that $P$. vampyrus was hunted mostly for subsistence $(83.3 \%, n=212$ ) (Figure 3$)$. Some hunters (9.6\%, $n=9.6)$ hunted Large Flying Foxes both for consumption and local trading (selling residual catch). Flying fox hunting mostly occurs in open spaces, e.g., dry rice fields, unplanted cornfields, roadways, and cleared spaces, during fly-out in the late afternoon $(55 \%, n=132)$ (Table 5). Other common hunting grounds for flying foxes were in the inundated forest $(25 \%, n=60)$ and in peat swamp forest $(4.6 \%, n=11)$. Some other hunters $(5 \%$, $\mathrm{n}=12$ ) also mentioned that they shot $P$. vampyrus while feeding at night in fruiting trees like Marang Artocarpos odoratissimus and Mango Mangifera indica.

The five most common hunting grounds for large flying foxes were on average $<2 \mathrm{~km}$ from the hunters' dwellings which implies that it was accessible and easy for them to hunt flying foxes. Kite and hook trapping was the most used hunting technique $(55 \%, n=132)$ (Table 6; Image S3-S5), particularly in open areas. Shooting was the next common technique used by the hunters (31.7\%, $n=76$ ) while the large flying foxes were in their roost sites or while feeding on fruiting trees.

A few respondents who were engaged in fishing sometimes observed Large Flying Foxes being caught in fishhooks (3.8\%, $n=9)$ and fishnets $(2.9 \%, n=7)$. Using slingshot $(2.5 \%, n=6)$ was the least common hunting technique used. Hunters incurred the least time in shooting $(0.8 \mathrm{~h})$ and in hunting flying foxes using a slingshot $(0.83 \mathrm{~h})$. On the other hand, hunters spent an average of three hours hunting flying fox using a kite trap. Hunters revealed that the length of time incurred

Table 5. Five Most Common Hunting Grounds of $P$. vampyrus in Agusan Marsh Wildlife Sanctuary with their respective Proximity (in kilometer) from the Hunters' Dwellings.

\begin{tabular}{|l|c|c|c|c|c|}
\hline Hunting Place & $\mathbf{N}$ & $\%$ & $\begin{array}{c}\text { Range } \\
\mathbf{( k m )}\end{array}$ & $\begin{array}{c}\text { Average } \\
\text { Distance } \\
\mathbf{( k m )}\end{array}$ & $\begin{array}{c}\text { Standard } \\
\text { Error }\end{array}$ \\
\hline $\begin{array}{l}\text { Open space/ } \\
\text { areas (rice field, } \\
\text { roadways, cornfield } \\
\text { etc) }\end{array}$ & 132 & 55 & $\begin{array}{c}0.001 \\
-6\end{array}$ & 1.3 & 0.120 \\
\hline Inundated forest & 60 & 25 & $0.02-7$ & 1 & 0.270 \\
\hline $\begin{array}{l}\text { Fruiting trees } \\
\text { (feeding ground) }\end{array}$ & 12 & 5 & $0.02-3$ & 1 & 0.270 \\
\hline Peat swamp forest & 11 & 4.6 & $0.03-4$ & 1.9 & 0.390 \\
\hline Settlements & 7 & 2.9 & $0.001-3$ & 0.67 & 0.330 \\
\hline
\end{tabular}


Frequency of patrolling/monitroing by DENR employees/law enforcers
15.4

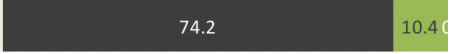

Frequency of Patrolling/Monitoring P.vampyrustrading by the local patrollers
12.

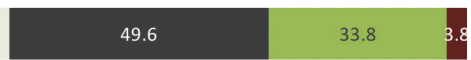

Frequency of Patrolling/Monitoring P.vampyrus huntingby the local patrollers
13.

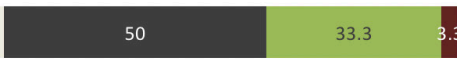

$20-40-60-80-100$

120

Never Hardly Ever $<1$ time/month) $\square$ Regularly (>1 time/month) @Frequently (>1 time/week)

Figure 2. Frequency of Monitoring or Patrolling by the forest wardens and government enforcers in the hunting grounds of $P$. vampyrus as perceived by the hunters in Agusan Marsh Wildlife Sanctuary.

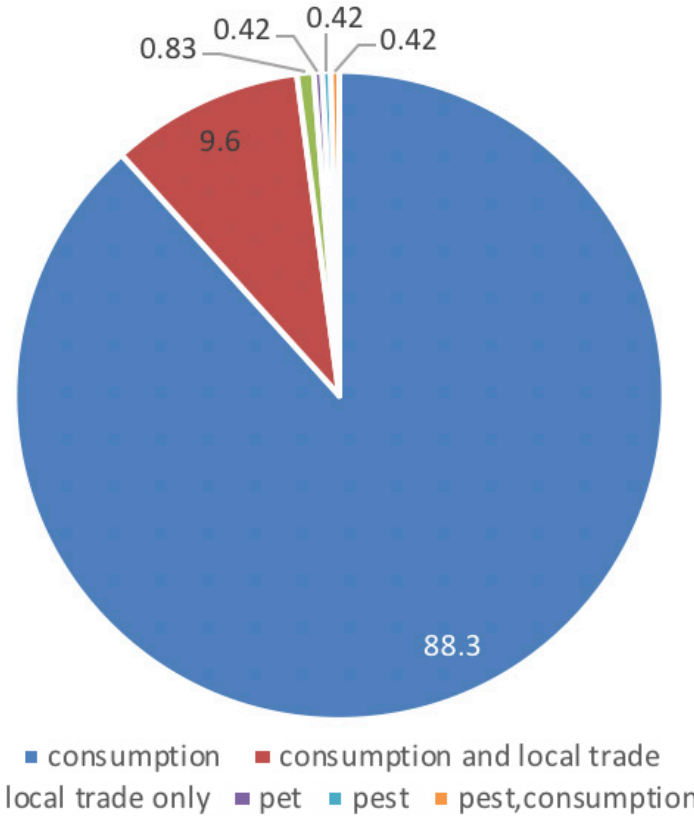

Figure 3. Motivations of hunters in hunting P. vampyrus in Agusan Marsh Wildlife Sanctuary

for hunting is primarily dependent on weather, wind direction, hunting skill, and location. Hunters using kite traps usually set up the kite at 1600-1900 h.

It was also found that the hunting frequency in 2012 (mean= 9.5) was higher than in 2016 (mean= 4.6) (Table S2). A Mann-Whitney $U$ test indicated that this difference was statistically significant, $U\left(N_{2012}=188\right.$, $\left.N_{2016}=91,\right)=7969.5, z=-0.932, p=<0.01$. Likewise, the number of individuals hunted per year was also higher in 2012 (mean= 25.6) than in 2016 (mean= 10.3). A Mann-Whitney $U$ test indicated that this difference was statistically significant, $U\left(N_{2012}=188, N_{2016}=91,\right)=7568$, $z=-1.5639, p=<.01$.
Table 6. Five Most Common Techniques Used in Hunting $P$. vampyrus in Agusan Marsh Wildlife Sanctuary with their respective Hunting Time Allocation (hour).

\begin{tabular}{|l|c|c|c|c|c|}
\hline $\begin{array}{l}\text { Hunting } \\
\text { technique }\end{array}$ & $\mathbf{N}$ & $\%$ & $\begin{array}{c}\text { Range } \\
\text { (hr) }\end{array}$ & $\begin{array}{c}\text { Average } \\
\text { Time } \\
\text { (hr) }\end{array}$ & $\begin{array}{c}\text { Standard } \\
\text { Error }\end{array}$ \\
\hline $\begin{array}{l}\text { Kite and hook } \\
\text { trapping }\end{array}$ & 132 & 55 & $1-5$ & 3 & 0.060 \\
\hline Shooting (gun) & 76 & 31.7 & $0.2-4$ & 0.80 & 0.050 \\
\hline Fishhook & 9 & 3.8 & $5-8$ & 7 & 0.410 \\
\hline Fish netting & 7 & 2.9 & $5-12$ & 7.6 & 1.050 \\
\hline Using slingshot & 6 & 2.5 & $0.5-1$ & 0.83 & 0.110 \\
\hline
\end{tabular}

\section{Driving Factors that Influence Flying fox Hunting}

A multiple regression model explained a statistically significant amount of variance in hunting frequency, $\mathrm{F}=4.123, p=0.003, R^{2}=0.07$ (Table S3). Average daily income was a significant predictor of hunting frequency, $B=-0.019, t=-2.025, p=0.04$. The lower the daily income of the hunter, the more likely that he would hunt $P$. vampyrus more often than those with higher income. Engagement of the hunter in any conservationrelated activities $(B=-4.728, t=-0.230, p=0.20)$ and distance of the hunter's dwelling to the hunting area ( $b=-0.965, t=-2.025, p=0.04)$ were likewise predictors of hunting frequency. Hunters who are not engaged in any conservation-related activities and those who live nearer to the hunting area are those who would hunt more frequently.

Similarly, a statistically significant amount of variance in hunting quantity was explained by a multiple regression model, $\mathrm{F}=5.084, p=0.02, R^{2}=0.06$ (Table S4). Average daily income $(b=-0.046, t=-2.50, p=0.010)$ and hunter's engagement in any conservation-related activities ( $b=-11.285, t=-2.51, p=0.010)$ were also found to be negatively associated with hunting quantity. 
Moreover, hunting time allocation $(\beta=1.495, t=2.077$, $p=0.040$ ) was found to be positively associated with hunting quantity. The more time allocated in hunting $P$. vampyrus, the higher the catch.

\section{DISCUSSION}

Understanding human-flying fox interaction is essential to effective long-term conservation, efficient law enforcement, and persistence of the flying fox population without compromising human welfare. This study shows the importance of determining the demographic, socio-economic and cultural background of flying fox hunters; level of conservation awareness, perceptions, and hunting drivers in informing adaptive flying fox conservation in AMWS and other protected areas in the Philippines and in other tropical countries.

\section{Socio-demographic and economic background of} hunters

The study shows the socioeconomic vulnerability of the indigenous and local communities in AMWS due to low daily wage (Php 182.50 or <4 USD during the dry season and Php 123.63 or <3 USD during the wet season) which is below the poverty threshold (Albert et al. 2018). Other contributing factors to the poor economic condition in AMWS include a high number of household dependents, lack of diversified income sources, and annual flooding. Most economic activities are influenced by the seasonal flood cycle in the marsh, availability of natural resources, and occurrence of drought (DENR 2001; Tomas et al. 2011). Rice and corn farming and fishing are the most common livelihoods in AMWS. It is during the first quarter of the year (December-March) that hunger among the communities is greater due to reduced economic activities and decreasing food supply, e.g., limited farm produce and low fish catch as this is the flood season (Tomas et al. 2011). Switching from farming to fishing is a common survival strategy in the flooded areas. It has been more challenging to those who do not have any fishing skills and no other supplementary income during the flood season.

The second quarter (April-July) is the dry season and the financial crisis is still commonly experienced due to the depletion of financial resources during the flood period and high expenses incurred for land preparation (planting season) and for school expenses of their children in March and June as the closing and opening of classes, respectively (Tomas et al. 2011). Drought is one of the most challenging phenomena to farmers during the dry season which adversely affects their produce. Unpredictable weather is experienced from August to November resulting in varying crop yield and fish catch (Tomas et al. 2011). The study also shows that only a few households have a supplementary source of income, e.g., rubber tapping, fish vending, food peddling, livestock raising (pigs and chickens), small stores, seasonal carpentry, farm services, motor driving, boat driving, and domestic services.

\section{Flying Fox Hunting Patterns and Intensity in AMWS}

Excessive hunting is considered a major threat particularly to the pteropodid bats (Schipper et al 2008; Mickleburgh et al. 2009; Mildenstein et al. 2016). Flying fox hunting is rampant in southeastern Asian countries where bats are abundant; poverty and food insecurity are high and enforcement is poor (Jenkins \& Racey 2008; Scheffers et al. 2012; Raymundo \& Caballes 2016; Mildenstein et al. 2016; Tanalgo et al. 2016; Tanalgo 2017). Hunting aside from logging and agricultural conversion is identified as the major threats specifically to Philippine bats (Tanalgo \& Hughes 2019). But even in protected areas of the country, subsistence hunting is rampant, e.g., Sierra Madre (Scheffers et al. 2012) and Mt. Apo National Park (Tanalgo 2017). Financially poor communities are more likely to hunt wildlife to satisfy their basic needs (Duffy et al. 2016), e.g., households with low living standards and smaller farms in Palawan were found to more likely hunt wildlife and spend greater hunting effort (Shively 1997). Likewise, this study shows that the low income of the hunters explains the prevalent flying fox hunting in AMWS.

The use of kite with string hooks was the most common flying fox hunting tool (Image S3) in AMWS which according to some indigenous key informants was introduced by a non-indigenous hunter. Although the use of kites and hooks has become famous in the area, some hunters still use air guns to hunt flying foxes in their roost sites. It is of major conservation concern when kite-and-hook hunters frequently catch females with lactating pups due to a lack of seasonal hunting regulation. Likewise, shooting is also of conservation concern because flying foxes have high roost site fidelity and they likely return to their preferred roost sites where hunting occurred (Stier \& Mildenstein 2005; Mildenstein 2016) which will likely cause population reduction (Mildenstein 2012).

Most of the flying fox hunters are 21-50 years old since the kite-and-hook trapping technique requires skill, strength and stamina. It requires a kite operator to fly the kite at $1600 \mathrm{~h}$ in the afternoon when the flying foxes 
start to come out from the roost sites. Ideal kite-andhook hunting sites are in open areas such as dried rice fields and unused corn fields. Hunters who live nearer to hunting areas are those who hunt more intensely due to greater ease and better accessibility. The adult kite operator would skillfully maneuver the kite and hooks with two other assistants (mostly 9-12 years old) who kill the catch by smashing the head with a hard object (Image S4). Both adult and child hunters did not mind the hunting risks at all, e.g., snake bite and injury, to meet their subsistence needs.

Some of the adult Manobo hunters (40-50 years old) mentioned that in 2000-2005, they used to see plenty of flying foxes and catch $>10$ Large Flying Foxes in 2-3 hours. Currently, based on ocular observation, they said that there is a gradual decrease in the flying fox population in AMWS and their catch has reduced to $<10$ in 2-3 hours. Hunting time allocation came out as one of the significant factors that influence hunting quantity in this research. If the hunters wanted to have more catch, they had to extend their kite trapping time. Besides, some older hunters also observed that flying fox roosting sites are now farther from the settlements, usually in undisturbed areas. Hence, kite and hook hunting has become more commonly preferred technique.

If the three hunters catch more than five flying foxes, the residual catch will be sold to their neighbors for Php 25-50 (<1 USD) each for quick cash to buy food, e.g., rice, viand, spices, and snacks in school for the kids. Some hunters will sell the residual catch to a certain middleman or reseller nearby who would resell the flying foxes (live or dressed) to a nearby town for Php 40-150 (<1-3 USD) depending on the flying fox size and the buyer. In Pisan, Cotabato, the price is also $<1$ USD (Tanalgo et al. 2016). The price in Sierra Madre is $>3$ USD where even local officials and law enforcers actively hunt Pteropus bats (Scheffer et al. 2012). Some local officials, government employees, enforcers and businessmen in AMWS were also mentioned by the hunters as their flying fox buyers on an order basis via mobile phone for Php 50-150 or 1-3 USD each usually for social drinking. There was one restaurant owner in a certain town who mentioned that in 2012-2013, he used to buy dressed flying foxes for Php 40 (<1 USD) each on an order basis or from walk-in peddlers. He served best seller cooked flying fox meat for Php 200 (4 USD) per serving. Warning from some enforcers has eventually stopped him from serving flying fox meat.

\section{POTENTIAL SOLUTIONS tO REgULATE FLYING FOX HUNTING IN AMWS}

Based on what we have learned from the socioeconomic, cultural, and environmental conditions as well as the hunting intensity in AMWS, we propose the following bottom-up conservation approaches:

\section{Engagement of indigenous and local communities in conservation}

The current study has emphasized that engagement of the communities with any conservation-related activities is negatively associated with hunting intensity in AMWS. This suggests that the involvement of indigenous and local people in relevant activities is vital for sustainable conservation action in the sanctuary and in other protected areas. Engaging local communities coupled with the increase of conservation awareness may effect positive changes in attitudes and behavior (Aziz et al. 2017). Encouraging participation of the local communities can help instill positive support to successful governance including law implementation and human-wildlife management (Velho et al. 2016; Milda et al. 2020) particularly if the local communities have high motivation towards wildlife protection (Conney et al. 2017).

The majority of them have recognized conservationrelated activities in the sanctuary. However, only a few of them were engaged in the said activities. Hence, training and hiring them as local research assistants in any flying fox research, e.g., population monitoring, human-bat conflict investigations, and involving them in the establishment of local conservation sites (e.g., Baral et al. 2014), creation of wildlife information centers, and in local outreach programs might increase their conservation awareness and divert their time to hunt. With proper capacity building, empowerment, and good incentives, hunters can be employed as patrollers to protect flying foxes using the "poachers to protectors" mechanism.

\section{Adaptive Information, Education and Communication Campaign (IEC)}

The involvement of 9-12-year old kids as hunting assistants to either their father, uncle, brother or neighbor is quite disturbing. This suggests the urgent need to integrate wildlife conservation in K-12 curricula. Conservation education must be provided to school children since conservation attitude is developed right from the earliest years (Jacobson 1995). The academe (nearby universities) and conservation experts must coordinate with the Department of Education to train 
the grade school and secondary (junior and senior levels) school teachers on flying fox conservation. Science books and lessons must integrate ecological services of threatened flying foxes, e.g., P. vampyrus and the implication of Wildlife Act or RA 9147 to conservation. Younger audiences might be receptive to positive information about flying foxes (Aziz et al. 2017). Educating the kids will surely have positive outcomes in their attitudes and disposition (Ardoin et al. 2018) towards wildlife conservation. Hence, flying foxconservation-themed science fair activities, e.g., quiz bees, debates, essay writing contests, and the postermaking contests might help develop the emotional attachment of children to flying foxes.

The parents and teachers association assembly can be a strategic avenue where the trained teachers can promote conservation to the older generation. The environmental education programs and approaches for schools and the local communities shared by Trewhella et al. (2005) and Kingston et al. (2006) can be adopted. It must include a simplified and comprehensible illustration of the indirect benefits of flying foxes to their livelihood as farmers and fishermen and the disadvantages of excessive hunting. Given the hunters' low awareness of the Wildlife Act, there must be a clearer explanation of its content and its conservation implication.

The target audience of conservation IECs must also include enforcers, government employees, and business owners since some of them were found to be part of the local trade chain. Flying fox conservation and wildlife act posters must be posted in hunting areas, e.g., fly-outs and roosting sites; public places, e.g., churches, markets, public transport terminals, government offices, and schools. Famous festivals, e.g., the 'Naliyagan' festival in Agusan del Sur may also include flying fox mascot parade, relevant film showing, games, and contests. Periodic assessment of IEC impacts is also important to improve awareness and outreach programs in regulating hunting, trading, consumption, and protecting habitats.

\section{Improved law enforcement}

It is stated in Chapter 3, Article 1, Section 7 of the Philippine Wildlife Act or RA 9147 that the collection of wildlife by indigenous people may be allowed for traditional use (e.g., food and medicine) and not primarily for trade: Provided, furthermore, that collection and utilization for said purpose shall not cover threatened species (DENR 2011). The difficulty of enforcing RA 9147 in AMWS can be explained by the strong dependence of the indigenous and local communities on the threatened flying fox, e.g., P. vampyrus meat for consumption. There were already confiscations of kites and guns, warnings, and restrictions given by the DENR in 2015-2016. But the poor communities in AMWS who lack adequate understanding of RA 9147, ecological values of flying foxes, and their conservation status continued hunting and engaged in local trading.

Furthermore, the infrequent or irregular patrolling scheme of the local wardens and the DENR enforcers could be attributed to a few local wardens and their minimal compensation (more or less Php 1,500 or $<30$ USD per quarter). No flying fox hunter was fined, convicted, and jailed in 2017-2018. Is the criminalization of hunting a threatened flying fox (e.g., P. vampyrus) an ethical or practical solution to protect the species in areas where hunting is part of their culture and which also serves as their safety net? This question is not only for AMWS context but also to other areas where the main hunting motivations are subsistence and economic incentives.

In this context, hunting limits (science-based quota per week or month) or perhaps allowing the hunters to focus on non-threatened (locally abundant) mammals may be a more effective and culturally adaptive regulation scheme than through strict legal enforcement. However, to balance species conservation and human welfare, there must be sustainable and seasonal hunting policies. This primarily requires hunting sustainability studies that include periodic flying fox population monitoring, hunting yields, hunting intensity, consumption rate, human population, and scenario building which are among the major research gaps in the Philippines. These are important information to accurately quantify the impacts of harvest in the future and the species extirpation tipping point. More research of this kind must be conducted within and outside Protected Areas to inform sustainable hunting policy interventions.

Increased investment in patrolling is necessary for hunting regulation and for increased detection of illegal activities (Jachman \& Billeouw, 1997; Johnson et al. 2016), e.g., flying fox trading and violation against sciencebased hunting quotas in AMWS. The government must provide funds for capacity building, regular patrolling, a sufficient number of patrollers with good compensation, patrolling equipment, and technology. These are very important for hunting regulation (Milda et al. 2020) particularly to monitor hunting considering hunting quotas and prescribed hunting season.

\section{Local food security and sustainable livelihood}

As discussed above, flying fox hunting in AMWS has been part of 'Manobo's' culture and has become 
the safety net (protein source) of the poor indigenous communities. The strong dependence on wild meat in AMWS is quite common in rural areas of other marginalized and poor countries where wildlife provides immediate food security, protein source, livelihood, and income source (MEA 2005; Pailler 2005; Nasi et al. 2008; Brashares et al. 2011; Swamy \& Pinedo-Vasquez 2014; Fa et al. 2015).

Hence, poverty alleviation will likely help in regulating wildlife resources (Robinson \& Bennett 2002; Swamy \& Pinedo-Vasquez 2014). Alternative incomegenerating strategies must be promoted in AMWS to reduce dependence on flying foxes. Appropriate and adequate support must be provided for the fisheries and agricultural sector to increase local food security. Support measures must include capacity-building for sustainable agriculture (e.g. organic vegetable farming, livestock husbandry, use of flood and drought-resistant crops) and sustainable fisheries (no using of electric and other illegal fishing techniques), indigenous handicraft making, providing micro-finance for farming, subsidizing farming and aquaculture inputs and improvement of farm-to-market accessibility.

Further measures to increase livelihood security include eco-tourism. AMWS has been identified as the primary tourism resource of the province of Agusan del Sur (DENR 2011). With appropriate planning, adequate government support, and effective implementation, ecotourism in AMWS will provide livelihood and income source diversification to the local communities and promote conservation. AMWS has terrestrial, wetland, and freshwater ecosystems (59 lakes and 5 rivers), harboring unique and pristine types of habitats, several species, and important nesting sites for migratory and resident birds (DENR 2011). Appropriate eco-tourism products and packages will be developed employing the local communities, e.g., river cruise, bird and flying fox watching, kayaking, and eco-trail on boardwalks, among others.

\section{CONCLUSIONS}

Flying fox hunting in AMWS is intricately linked with the economic, social, cultural, environmental, and ethical challenges. Low income, lack of engagement in conservation-related activities, the proximity of hunter's dwelling to the hunting area, and hunting time allocation came out as the significant contributing factors to hunting intensity in AMWS. Although low awareness of the Wildlife Act, no attendance to IECs on ecological values of flying foxes, infrequent patrolling, and poor law enforcement were not among the significant drivers but to some extent, are also important factors to consider in the design of long-term flying fox conservation programs. To make policy interventions more realistic and sustainable, the approaches in regulating flying fox hunting in AMWS must not be solely focused on flying fox conservation at the expense of livelihood and food security, nutrition, and well-being of the communities.

Adaptive and flexible approaches that reconcile and balance the dependence of the poor communities on wild meat and the conservation of threatened flying fox population, e.g., P. vampyrus must be considered. With many constraints in totally banning hunting in areas with poor and wild resource-dependent indigenous people, sustainable flying fox hunting is the most reasonable option to promote conservation and food security. This requires intensive research on the dynamics of flying fox hunting, consumption and trading extent, population data (spatial and temporal) and scenario building for the predictive impacts of hunting on the depletion particularly of threatened flying fox species, e.g., P. vampyrus. This will scientifically inform policy interventions on the setting of sustainable hunting quota (number of catch per time period) in the sanctuary with the prescribed hunting technique, in the right hunting areas during the prescribed season.

Achieving successful conservation and positive behavioral change requires a combination of effective information and education communication to different sectors, engagement of the local communities in research and conservation, improved patrolling scheme to assure sustainable hunting limits (quota) and to ban trading, capacity building for sustainable livelihood programs and diversification of income sources.

\section{REFERENCES}

Albert, J.R.G., G.F. Santos \& J.F.V. Vizmanos (2018). Profile and determinants of the middle-income class in the Philippines. PIDS Discussion Paper No. 2018-20. Quezon City, Philippines: Philippine Institute for Development Studies. https://pidswebs.pids.gov.ph/ CDN/PUBLICATIONS/pidsdps1820.pdf (Accessed 15 April 2020)

Ardoin, N.M., A.W. Bowers, N.W. Roth \& H. Holthuis (2018). Environmental education and K-12 student outcomes: a review and analysis of research. The Journal of Environmental Education 49: 1-17. https://doi.org/10.1080/00958964.2017.1366155

Apan, A., L.A. Suarez, T. Maraseni \& J.A. Castillo (2017). The rate, extent and spatial predictors of forest loss (2000-2012) in the terrestrial protected areas of the Philippines. Applied Geography (81): 32-42. https://doi.org/10.1016/j.apgeog.2017.02.007

Aziz, S.A., R.C. Gopalasamy, G. Xingli, P.M. Forget \& C.A. Ahimsa (2017). Coexistence and Conflict between the Island Flying fox (Pteropus hypomelanus) and Humans on Tioman Island, Peninsular 
Malaysia Human Ecology, 45: 377-389. https://doi.org/10.1007/ s10745-017-9905-6

Aziz, S.A., K.R. McConkey, K. Tanalgo, T. Sritongchuay, M.R. Low, J.Y. Yong, T.L. Mildenstein, C.E. Nuevo-Diego, V. Lim \& P.A. Racey (2021). The critical importance of Old World fruit bats for healthy ecosystems and economies. Frontiers in Ecology and Evolution 9: 181. https:// www.frontiersin.org/articles/10.3389/fevo.2021.641411/full?utm source=S-TWT\&utm_medium=SNET\&utm_campaign=ECO_FEVO_ XXXXXXXX_auto-dlvrit

Baral, H.S., B. Sahgal, S. Mohsanin, K. Namgay \& A.A. Khan (2014) Species and habitat conservation through small locally recognized and community managed special conservation sites. Journal of Threatened Taxa 6(5): 5677-5685. https://doi.org/10.11609/JoTT. o3792.5677-85

Bates, P., C. Francis, M. Gumal, S. Bumrungsri, J. Walston, L. Heaney \& T. Mildenstein (2008). Pteropus vampyrus. In: IUCN 2008. The IUCN Red List of Threatened Species 2008. Downloaded on 18 October 2018. https://doi.org/10.2305/IUCN.UK.2008.RLTS. T18766A8593657.en

Bendsen, N., A. Gonzales, M.C.S. Jasma \& F. Temur (2017). Negotiating with the Spirits: Recognizing the Conservation Values of Indigenous Knowledge Systems and Practices of the Agusanon Manobo, Agusan del Sur, Philippines. GIZ-COSERAM.

Brashares, J.S., C.D. Golden, K.Z. Weinbaum, C.B. Barrett \& G.V. Okello (2011). Economic and geographic drivers of wildlife consumption in rural Africa. Proceedings of the National Academy of Sciences, 108: 13931-13936.

Clayton, L. \& E.J. Milner-Gulland (2000). The trade in wildlife in North Sulawesi, Indonesia, pp. 473-496. In: Robinson, J.G. \& E. Bennet (eds.). Hunting for Sustainability in Tropical Forests. Columbia University Press, New York.

Cooney, R, D. Roe, H. Dublin, J. Phelps, D. Wilkie, A. Keane, H. Travers, D. Skinner, D.W.S. Challender, J.R. Allan \& D. Biggs (2016). From Poachers to Protectors: Engaging Local Communities in Solutions to Illegal Wildlife Trade. Conservation Letters 10(3) https://doi. org/10.1111/conl.12294.

Corlett, R.T. (1998). Frugivory and seed dispersal by vertebrates in the Oriental (Indomalayan) Region. Biological Reviews of the Cambridge Philosophical Society 73: 413-448.

DENR (2001). Agusan marsh management plan. Agusan del Sur, Department of Environment and Natural Resources, Philippines.

DENR (2011). Watershed Rehabilitation, Biodiversity Conservation, and Related Social and Indigenous Peoples Development. Agusan River Basin Integrated Water Resources Management Project PPTA TA NO. 7258-PHI Final Report Volume 3: supporting reports.

DENR (2011). Wildlife Resources Conservation and Protection Act. https://www.cbd.int/doc/measures/abs/msr-abs-ph3-en.pdf. Accessed 17 March 2015.

DENR Caraga (2015). The Agusan March Wildlife Sanctuary Management Plan (2015-2019). PAWCZMS, DENR-Caraga, 91 pp.

Duffy, R., F.S. John, B. Buscher \& D. Brockington (2016). Toward a New Understanding of the Links between Poverty and Illegal Wildlife Hunting. Conservation Biology 30(1): 14-22. https://doi. org/10.1111/cobi.12622

Epstein, J.H., K.J. Olival, J.R.C. Pulliam, C. Smith, J. Westrum, T. Hughes, A.P. Dobson, A. Zubaid, S.A. Rahman, M.M. Basir, H.E. Field \& P. Daszak (2009). Pteropus vampyrus, a hunted migratory species with a multinationational home-range and a need for regional management. Journal of Applied Ecology (46): 991-1002. https://doi.org/10.1111/j.1365-2664.2009.01699.x

Fa, J.E., J. Olivero, M.A. Farfán, A.L. Márquez \& J.M. Vargas (2015) Correlates of bushmeat in markets and depletion of wildlife. Conservation Biology 29(3): 805-815. https://doi.org/10.1111/ cobi.12441

Friant, S., S.B. Paige \& T.L. Goldberg (2015). Drivers of Bushmeat Hunting and Perceptions of Zoonoses in Nigerian Hunting Communities. PLoS Neglected Tropical Diseases 9(5): e0003792. https://doi.org/10.1371/journal.pntd.0003792

Gonzalez, J.C.T., C. Layusa, L. Afuang, M. Duya, D. Tabaranza, C.
Esapaňola, W. Van de Ven, A. Diesmos, R. Causaren, M. Diesmos, R. Lagat, N. Realubit, E. Sy, I. Lit, Jr., J. Naredo, E. Lastica-Ternura, S. Pasicolan, A. Tagtag, J. De Leon, T. Lim \& P. Ong (2018). Review and update of the 2004 National List of Threatened Terrestrial Fauna of the Philippines. Sylvatrop, The Technical Journal of Philippine Ecosystems and Natural Resources 28(1): 73-144.

Hammer, Ø., D.A.T. Harper \& P.D. Ryan (2001). Past: Paleontological Statistics Software Package for Education and Data Analysis. Palaeontologia Electronica 4(1): 4-9. http://palaeo-electronica. org/2001_1/past/issue1_01.htm

Heaney, L., D. Balete, M. Dolar \& P. Ong (1998). A Synopsis of the Mammalian Fauna of the Philippine Islands. Fieldiana Zoology 88: $1-61$.

Ibanez, J.C. \& S.T. Bastian Jr. (2015). Are sago palm Metroxylon sagu growths in Agusan Marsh Wildlife Sanctuary a critical habitat for endemic wildlife? A Project Terminal Report. University of the Philippines Center for Integrative Development Studies and University of the Philippines in Mindanao, $33 \mathrm{pp}$.

International Union for the Conservation of Nature (2014). The IUCN Red List of threatened species. Version 2014.3. Downloaded on 14 September 2018. Retrieved from http://www.iucnredlist.org

International Union for the Conservation of Nature (2021). The IUCN Red List of Threatened Species. Version 2021-2. https://www. iucnredlist.org. Downloaded on [7 Aug 2021].

Ingle, N.R. \& L.R. Heaney (1992). A key to the bats of the Philippine Islands. Fieldiana: Zoology, new series 69: 1-44.

Jachmann, H. \& Billiouw, M. (1997). Elephant poaching and law enforcement in the Central Luangwa Valley, Zambia. Journal of Applied Ecology 34: 233-244.

Jacobson, S.K. (1995). Conserving Wildlife: International Education and Communication Approaches. Columbia University Press, New York.

Jenkins, R.K.B. \& P.A. Racey (2008). Bats as Bushmeat in Madagascar. Madagascar Conservation and Development 3: 22-30.

Johnson, A., J. Goodrich, T. Hansel, A. Rasphone, A. Saypanya, C. Vongkhamheng, Venevongphet \& S. Strinberg (2016). To protect or neglect? Design, monitoring, and evaluation of a law enforcement strategy to recover small populations of wild tigers and their prey. Biological Conservation 202: 99-109. https://doi.org/10.1016/j. biocon.2016.08.018

Kingston, T., A. Zubaid, G. Lim \& F. Hatta (2006). From research to outreach: Environmental education materials for the bats of Malaysia, pp. 21-29. In: Yahya N.A., E. Philip E. \& T. Ong (eds.). Proceedings of the best of both worlds conference on environmental education for sustainable development, 6-8 September 2005, Gemilang Press Sdn Bhd, Kuala Lumpur.

Kunz, T.H. \& D. Jones (2000). Pteropus vampyrus. Mammalian Species 642, 1-6.Kushosha, E. (2001). Education and environmental future. Malihai Magazine 5: 9-10.

Lee, R.J., A.J. Gorog, A. Dwiyahreni, S. Siwu, J. Riley, H. Alexander, G.D. Paoli \& W. Ramono (2005). Wildlife trade and implications for law enforcement in Indonesia: a case study from North Sulawesi. Biological Conservation 123: 477-488.

Mallari, N.A., N.J. Collar, P. McGowan \& S.J. Marsden (2016). Philippine protected areas are not meeting the biodiversity coverage and management effectiveness requirements of Aichi Target 11. Ambio 45(3): 313-322.

Mcllwee, A.P. \& L. Martin (2002). On the intrinsic capacity for increase of Australian flying-foxes (Pteropus spp. Megachiroptera). Australian Zoologist 32: 76-100.

McConkey, K.R. \& D.R. Drake (2006). Flying foxes cease to function as seed dispersers long before they become rare. Ecology 87: 271-276.

MEA (Millennium Ecosystem Assessment) (2005). Ecosystems and Human Well-being: Biodiversity Synthesis. World Resources Institute, Washington DC.

Mickleburgh, S., K. Waylen \& P. Racey (2009). Bats as bushmeat: a global review. Oryx 43: 217-234.

Milda, D., T. Ramesh, R. Kalle, V. Gayathri \& M. Thanikodi (2020). Ranger survey reveals conservation issues across Protected and 
outside Protected Areas in southern India. Global Ecology and Conservation 24: e01256. https://doi.org/10.1016/j.gecco.2020. e01256

Mildenstein, T.L. (2012). Conservation of endangered flying foxes in the Philippines: effects of anthropogenic disturbance and research methods for community-based conservation. Ph.D. Thesis, University of Montana, United States.

Mildenstein, T., I. Tanshi \& P. Racey (2016). Exploitation of bats for bushmeat and medicine, pp. 325-375. In: Voigt C. \& T. Kingston (eds.). Bats in the Anthropocene: Conservation of Bats in a Changing World. Springer Cham Heidelberg New York Dordrecht London, $605 \mathrm{pp}$

Myers, N., R.A. Mittermeier, C.G. Mittermeier, G. da Fonseca \& J. Kent (2000). Biodiversity hotspots for conservation priorities. Nature 403: 853-858. https://doi.org/10.1038/35002501

Nakamoto, A., K. Kinjo \& M. Izawa (2008). The role of Orii's flyingfox (Pteropus dasymallus inopinatus) as a pollinator and a seed disperser on Okinawa-jima Island, the Ryukyu Archipelago, Japan. Ecological Research 24: 405-414.

Nasi, R., D. Brown, D. Wilkie, E. Bennett, C. Tutin, G. van Tol \& T. Christophersen (2008). Conservation and use of wildlife-based resources: the bushmeat crisis. CBD Technical Series No.33. Montreal, Canada, Secretariat of the Convention on Biological Diversity and Center for International Forestry Research (CIFOR), Bogor, Indonesia, 50p.

Pailler, S. (2005). The necessity, complexity and difficulty of resolving the bushmeat crisis in west-central Africa. Journal of Development and Social Transformation 2: 99-107.

PEF (2008). Eastern Mindanao Biodiversity Corridor Conservation Framework. Philippine Eagle Foundation, Conservation International-Philippines, Department of Environment and Natural Resources, Davao City, Philippines, 95pp.

Posa, M.R.C., A.C. Diesmos, N.S. Sodhi \& T.M. Brooks (2008) Hope for threatened tropical biodiversity: Lessons from the Philippines. BioScience 58: 231-240. https://doi.org/10.1641/ B580309

Primavera, J.H. \& M.I. Tumanda (2007). The Agusan Marsh: A situationer with focus on scientific aspects. Proceedings of the $1^{\text {st }}$ Scientific Conference on the Agusan Marsh. Butuan City, Agusan Del Sur, Philippines. Philippine Council for Aquatic and Marine Research and Development.

Racey, P.A. \& A.C. Entwistle (2000). Life history and reproductive strategies in bats, pp. 363-414. In: Crighton, E. \& P.H. Krutzsch (eds.). Reproductive Biology of Bats. Academic Press, NY.

Raymundo, M.L. \& C.F. Caballes (2016). An insight into bat hunter behavior and perception with implications for the conservation of the critically endangered Philippine bare-backed fruit bat. Journal of Ethnobiology 36(2): 382-394.

Robinson, J.G. \& E.L. Bennett (2002). Will alleviating poverty solve the bushmeat crisis? Oryx 36: 332-332.

Scheffers, B.R., R.T. Corlett, A. Diesmos \& W.F. Laurance (2012) Local demand drives a bushmeat industry in a Philippine forest preserve. Tropical Conservation Science 5(2): 133-141. https://doi. org/10.1177/194008291200500203

Schipper, J. , J.S. Chanson, F. Chiozza, N.A. Cox, M. Hoffmann, V. Katariya, J. Lamoreux, A.S.L Rodrigues, S.N. Stuart, H.J. Temple, J. Baillie, L. Boitani, T.E. Lacher Jr, R.A. Mittermeier, A.T. Smith, D. Absolon, J.M. Aguiar, G. Amori, N. Bakkour, R. Baldi, R.J. Berridge, J. Bielby, P.A. Black, J. Blanc, T.M. Brooks, J.A. Burton, T.M. Butynski, G. Catullo, R. Chapman, Z. Cokeliss, B. Collen, J. Conroy, J.G. Cooke, G.A.B. da Fonseca, A.E. Derocher, H.T. Dublin, J.W. Duckworth, L. Emmons, R.H. Emslie, M. Festa-Bianchet, M. Foster, S. Foster, D.L. Garshelis, C. Gates, M. Gimenez-Dixon, S. Gonzalez, J.F. GonzalezMaya, T.C. Good, G. Hammerson, P.S. Hammond, D. Happold, M. Happold, J. Hare, R.B. Harris, C.E. Hawkins, M. Haywood, L.R. Heaney, S. Hedges, K.M. Helgen, C. Hilton-Taylor, S.A. Hussain, N. Ishii, T.A. Jefferson, R.K.B Jenkins, C.H. Johnston, M. Keith, J. Kingdon, D.H. Knox, K.M. Kovacs, P. Langhammer, K. Leus, R. Lewison, G. Lichtenstein, L.F. Lowry, Z. Macavoy, G.M. Mace, D.P.
Mallon, M. Masi, M.W. McKnight, R.A. Medellín, P. Medici, G. Mills, P.D. Moehlman, S. Molur, A. Mora, K. Nowell, J.F. Oates, W. Olech, W.R.L. Oliver, M. Oprea, B.D. Patterson, W.F. Perrin, B.A. Polidoro, C. Pollock, A. Powel, Y. Protas, P. Racey, J. Ragle, P. Ramani, G. Rathbun, R.R. Reeves, S.B. Reilly, J.E. Reynolds 3rd, C. Rondinini, R.G. Rosell-Ambal, M. Rulli, A.B. Rylands, S. Savini, C.J. Schank, W. Sechrest, C. Self-Sullivan, A. Shoemaker, C. SilleroZubiri, N. De Silva, D.E. Smith, C. Srinivasulu, P.J. Stephenson, N. Strien, B.K. Talukdar, B.L. Taylor, R. Timmins, D.G. Tirira, M.F. Tognelli, K. Tsytsulina, L.M. Veiga, J.C. Vié, E.A. Williamson, S.A. Wyatt, Y. Xie \& B.E. Young (2008). The status of the world's land and marine mammals: diversity, threat and knowledge. Science 322: 225-230. https://doi.org/ 10.1126/science.1165115

Sheherazade \& S. Tsang (2015). Quantifying the bat bushmeat trade in North Sulawsi, Indonesia, with suggestions for conservation action. GlobalEcology Conservaiton 3:324-330. https://www.sciencedirect. com/science/article/pii/S2351989415000049?via\%3Dihub

Shilton, L.A. \& R.J. Whittaker (2009). The role of pteropodid bats in reestablishing tropical forests on Krakatau, pp. 176-215. In: Fleming, T.H. \& P.A. Racey (eds.). Island Bats. Chicago University Press, Chicago.

Shively, G.E. (1997). Poverty, technology and wildlife hunting in Palawan. Environmental Conservation 24: 57-63.

Stier, S.C. \& T.L. Mildenstein (2005). Dietary habits of the world's largest bats: the Philippine Flying Foxes, Acerodon jubatus and Pteropus vampyrus lanensis. Journal of Mammalogy 86: 719-728. https://doi.org/10.1644/1545-1542(2005)086[0719:DHOTWL]2.0. $\mathrm{CO} ; 2$

Swamy, V. \& M. Pinedo-Vasquez (2014). Bushmeat harvest in tropical forests: Knowledge base, gaps and research priorities. Occasional paper 114. CIFOR, Bogor, Indonesia.

Tanalgo, K.C., R.D. Teves, F.R.P. Salvaña, R.E. Baleva \& J.A.G. Tabora (2016). Human-bat interactions in caves of South Central Mindanao, Philippines. Wildlife Biology in Practice 12(1): 1-14.

Tanalgo, K.C. (2017). Wildlife hunting by indigenous people in a Philippine protected area: a perspective from Mt. Apo National Park, Mindanao Island. Journal of Threatened Taxa 9(6): 1030710313. https://doi.org/10.11609/jott.2967.9.6.10307-10313

Tanalgo, K.C. \& A. Hughes (2018). Bats of the Philippine Islands-A review of research directions and relevance to national-level priorities and targets. Mammalian Biology 91: 46-56.

Tanalgo, K.C. \& A.C. Hughes (2019). Priority-setting for Philippine Bats using practical approach to guide effective species conservation and policy-making in the Anthropocene. Hystrix, the Italian Journal of Mammalogy 30(1): 74-83. http://www.italian-journal-ofmammalogy.it

Tomas, R.C., J.B. Manuta \& V.G. dela Rosa (2011). Too Much or Too Little Water: Adaptation Pathways of Agusan Marsh Communities. SLONGAN 1(27): 27-39.

Trewhella, W.J., K.M. Rodriguez-Clark, N. Corp, A. Entwistle, S.R.T. Garrett, E. Granek, K.L. Lengel, M.J. Raboude, P.F. Reason \& B.J. Sewall (2005). Environmental education as a component of multidisciplinary conservation programs: lessons from conservation initiatives for critically endangered fruit bats in the western Indian Ocean. Conservation Biology 19: 75-85.

Velho, N., U. Srinivasan, P. Singh \& W.F. Laurance (2016). Large Mammal Use of protected and community-managed lands in a biodiversity hotspot. Animal Conservation 19(2): 199-208. https:// doi.org/10.1111/acv.12234

World Resources Institute (2003). Earthtrends. Downloaded on 8 October 2018. Retrieved from http://earthtrends.wri.org

Wiles, G.J. \& A.P. Brooke (2009). Conservation threats to bats in the Pacific Islands and insular Southeast Asia, pp 405-459. In: Fleming, T.H. \& P.A. Racey (Eds.). Island Bats: Evolution, Ecology, and Conservation. Chicago University Press, Chicago, 560 pp.

Worboys, G.L. \& C. Winkler (2006). Natural Heritage, pp. 3-40. In: Lockwood M., G.L. Worboys \& A. Kothari (ed.). Managing Protected Areas: A Global Guide. Earthscan, London, Sterling, VA, 832 pp. 


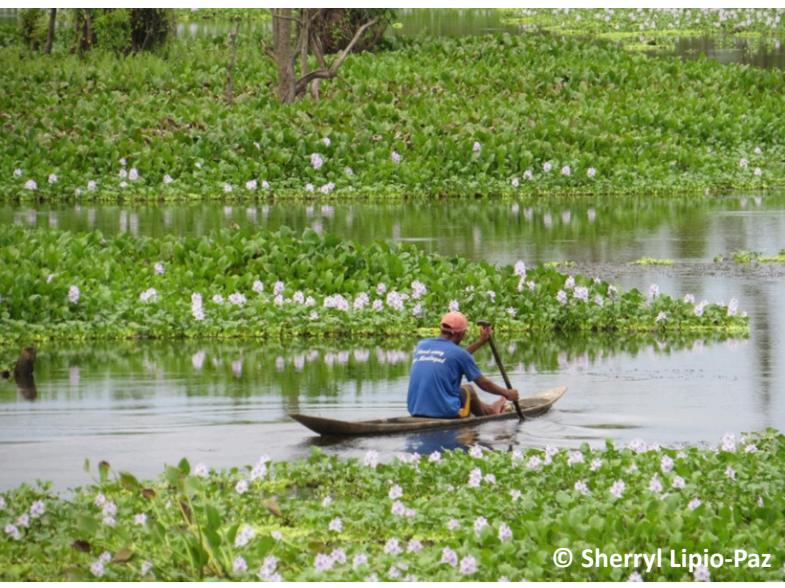

Image S1. Agusan Marsh Wildlife Sanctuary (Sitio Panlabuhan, Poblacion, Loreto, Agusan del Sur, Philippines).
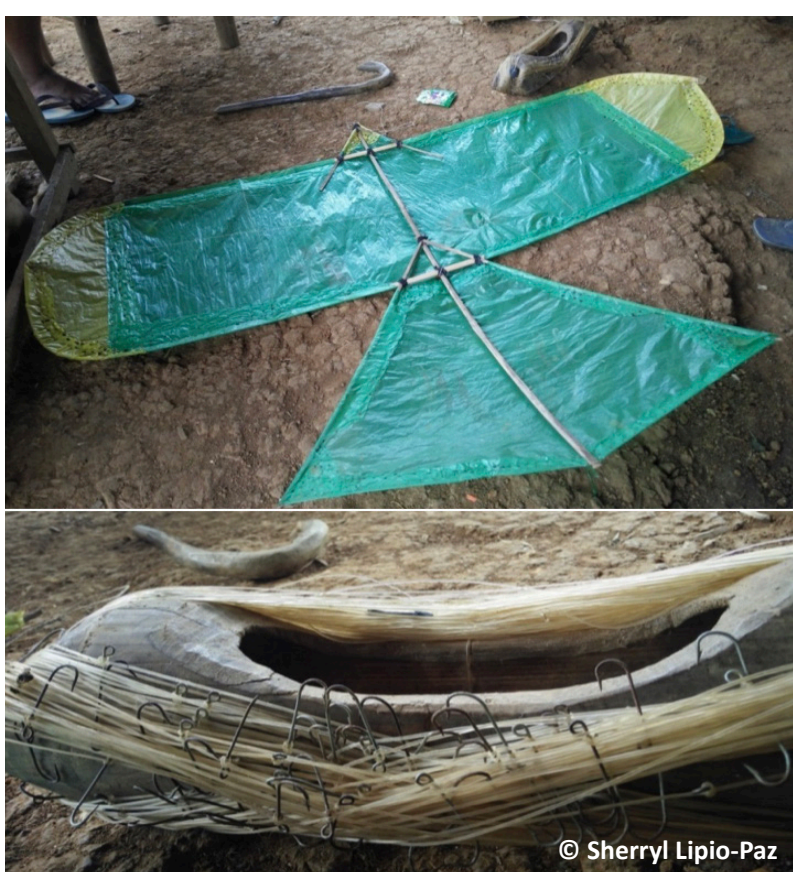

Image S3. Kite and hook materials commonly used in hunting flying foxes in Agusan Marsh Wildlife Sanctuary (upper picture: kite used by hunters; lower picture: kite string hooks to trap flying foxes)
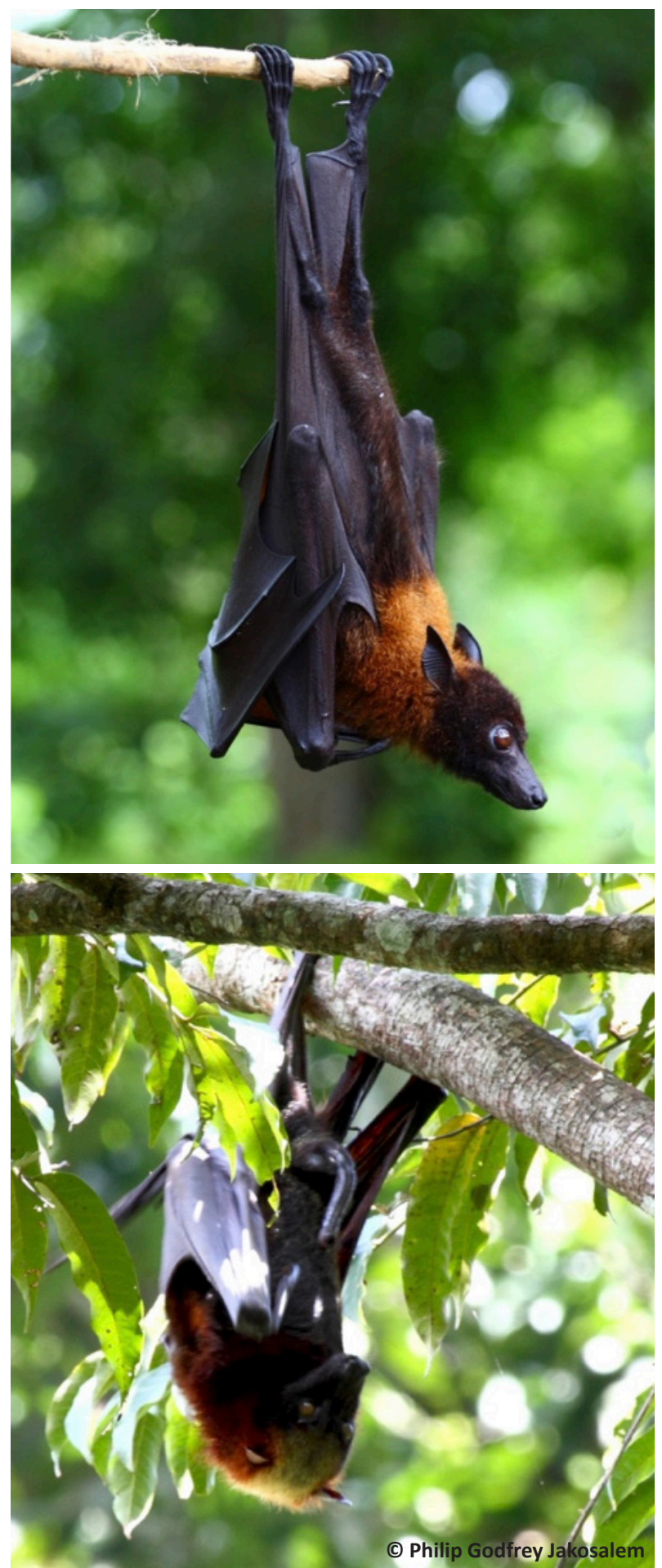

Image S2. Morphological differences of the Endangered $P$. vampyrus (Large Flying Fox) shown in the top picture and Critically Endangered Acerodon jubatus (Golden-crowned Flying Fox) shown in the bottom picture. The dorsal pelage of $P$. vampyrus is usually blackish brown and golden on the upper back, with the posterior margin sharply defined by a dark brown transverse line on the lower back, that ends in a narrow " $\mathrm{V}$ " at the nape and shoulders. Whereas, the dorsal pelage of $A$. jubatus is not completely blackish brown, and has a golden patch on top of the head extending to the ears, but lacks the dark brown transverse line on the lower back. 

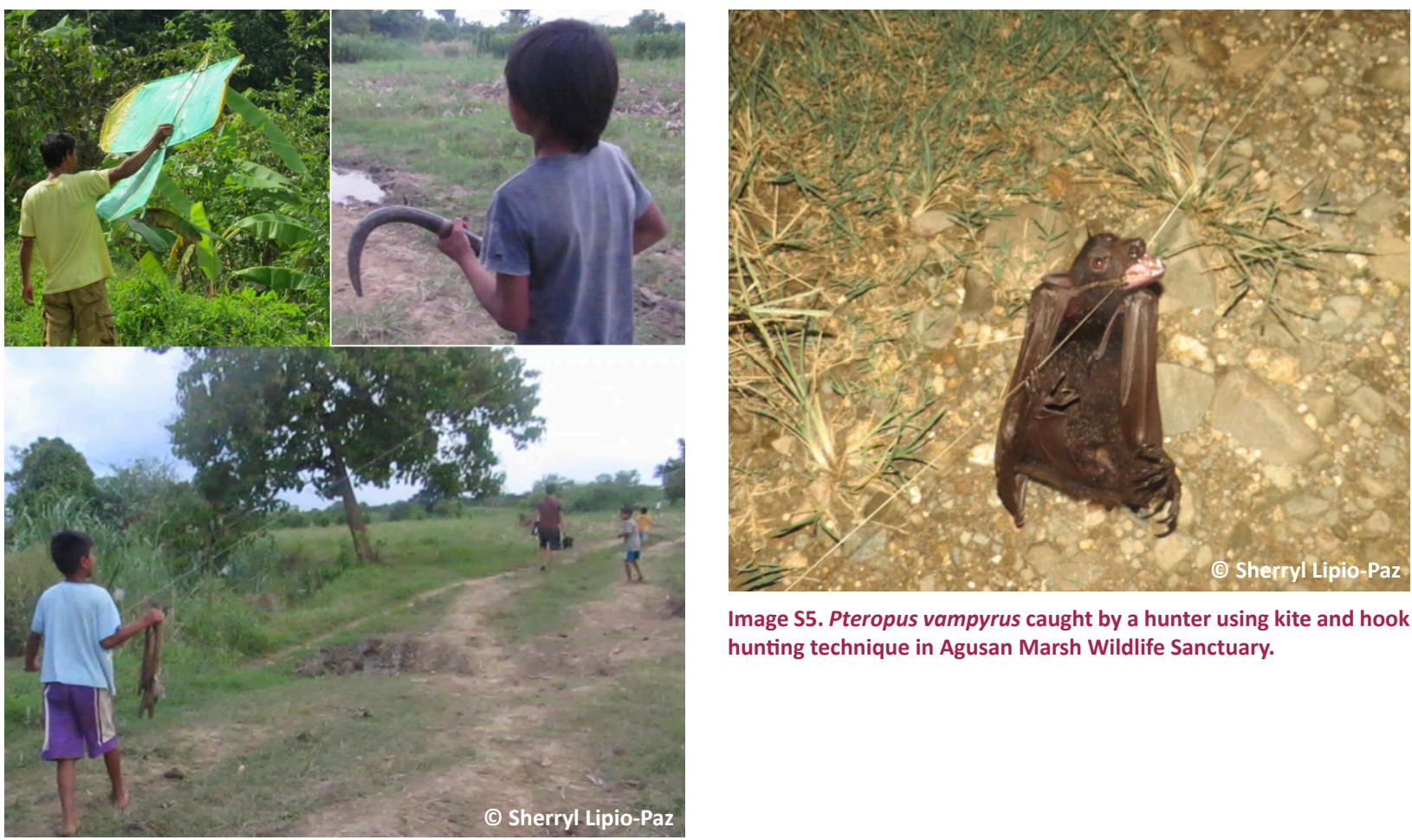

Image S5. Pteropus vampyrus caught by a hunter using kite and hook hunting technique in Agusan Marsh Wildlife Sanctuary.

Image S4. Kite and hook hunting of flying foxes in Agusan Marsh Wildlife Sanctuary starting at $1600-1700 \mathrm{~h}$ in the afternoon (upper left picture: adult kite operator (main hunter); upper right picture: child hunting assistant with a wooden material used to kill the catch; lower picture: young hunting assistants (9-12 years old).

Table S1. Five most common livelihoods of the $P$. vampyrus hunters in Agusan Marsh Wildlife Sanctuary during the dry and wet season ( $\mathrm{n}=\mathbf{2 4 0}$ ).

\begin{tabular}{|l|c|c|c|c|}
\hline \multirow{2}{*}{ Main livelihood } & \multicolumn{2}{|c|}{ Dry Season } & \multicolumn{2}{c|}{ Wet Season } \\
\cline { 2 - 5 } & Frequency & Percentage (\%) & Frequency & Percentage (\%) \\
\hline Rice farming & 144 & 60 & 84 & 35 \\
\hline Corn farming & 26 & 10.8 & 9 & 3.8 \\
\hline Fishing & 14 & 5.8 & 85 & 35.4 \\
\hline Rubber tapping & 11 & 4.6 & 8 & 3.3 \\
\hline Motorcycle Driving & 8 & 3.3 & 5 & 2.1 \\
\hline None & 2 & 0.83 & 37 & 15.4 \\
\hline
\end{tabular}

Table S2. Hunting Frequency and Quantity of $P$. vampyrus across different periods (1 month before the surveys in 2017, 2016 and 2012 ) in Agusan Marsh Wildlife Sanctuary as revealed by the hunters.

\begin{tabular}{|c|c|c|c|c|c|c|c|c|c|c|}
\hline \multirow[t]{2}{*}{ Variables } & \multicolumn{3}{|c|}{$\begin{array}{l}1 \text { month before the surveys in } 2017 \\
\qquad(n=27)\end{array}$} & \multicolumn{3}{|c|}{$2016(n=91)$} & \multicolumn{3}{|c|}{$2012(n=188)$} & \multirow{2}{*}{$\begin{array}{l}\text { Sig. } 2016 \\
\text { vs } 2012\end{array}$} \\
\hline & Range & Mean & SE & Range & Mean & SE & Range & Mean & SE & \\
\hline Hunting Frequency & $0-12$ & 0.54 & 0.13 & $0-96$ & 4.6 & 0.70 & $0-50$ & 9.5 & 0.79 & 0.001 \\
\hline Hunting Quantity & $0-50$ & 1.5 & 0.41 & $0-100$ & 10.3 & 1.4 & $0-100$ & 25.6 & 1.9 & 0.001 \\
\hline
\end{tabular}


Table S3. Driving factors of the frequency of hunting P. vampyrus in Agusan Marsh Wildlife Sanctuary.

\begin{tabular}{|l|c|c|c|c|}
\hline \multirow{2}{*}{ Variables } & \multicolumn{2}{|c|}{ Unstandardized Coefficients } & \multirow{2}{*}{$\mathbf{t}$} & \multirow{2}{*}{$\mathbf{p}$-value } \\
\cline { 2 - 3 } & Estimates, B & Std. Error & & \\
\hline (Constant) & 11.415 & 3.299 & 3.460 & $0.001^{* * *}$ \\
\hline No. of Family Members with income & 0.581 & 0.317 & 1.835 & $0.070^{\text {ns }}$ \\
\hline Average Daily Income & -0.019 & 0.009 & -2.025 & $0.040^{*}$ \\
\hline aEngagement in conservation-related activities & -4.728 & 2.287 & -2.067 & $0.040^{*}$ \\
\hline Distance to the hunting area (in $\mathrm{km}$ ) & -0.965 & 0.419 & -2.303 & $0.020^{*}$ \\
\hline
\end{tabular}

Legend: *** highly significant (significant at $\alpha=0.001$ ); ${ }^{* *}$ significant at $\alpha=0.01 ;{ }^{*}$ significant at $\alpha=0.05{ }^{\text {ns }}$ not significant at $\alpha=>0.05$ ${ }^{a}$ categorical variable: $1=$ member; $0=$ non-member

Dependent Variable: Frequency of Hunting; $R^{2}=0.07 ;$ ANOVA, F-statistic $=4.123$ with $p$ - value $=0.003$

Figure S5. Pteropus vampyrus caught by a hunter using kite and hook hunting technique in Agusan Marsh Wildlife Sanctuary.

\begin{tabular}{|l|c|c|c|c|}
\hline \multirow{2}{*}{\multicolumn{1}{|c|}{ Variables }} & \multicolumn{2}{c|}{ Unstandardized Coefficients } & \multirow{2}{*}{ t } & \multirow{2}{*}{ p-value } \\
\cline { 2 - 5 } & Estimates, B & Std. Error & & \\
\hline (Constant) & 26.022 & 6.114 & 4.256 & $<0.001^{* * *}$ \\
\hline Average Daily Income & -0.046 & 0.018 & -2.500 & $0.010^{* *}$ \\
\hline aEngagement in conservation-related activities. & -11.285 & 4.492 & -2.512 & $0.010^{* *}$ \\
\hline Hunting Time Allocation & 1.495 & 0.720 & 2.077 & $0.040^{*}$ \\
\hline
\end{tabular}

Legend: *** highly significant (significant at $\alpha=0.001$ ); ${ }^{* *}$ significant at $\alpha=0.01{ }^{*}$ significant at $\alpha=0.05$ ns not significant at $\alpha=>0.05$ a categorical variable: $1=$ member; $0=$ non-member

Dependent Variable: Frequency of Hunting; $R^{2}=0.06$; ANOVA, F-statistic $=5.084$ with $p$-value $=0.002$.

Tagalog abstract: Walang dokumentadong pag -aaral sa panghuhuli ng mga paniki ang ginawa sa Agusan Marsh Wildlife Sanctuary (AMWS) na kilalang nagtataglay ng maraming nanganganib na mga buhay-ilang. Ang mga uri ng paniki tulad ng Large Flying Fox o Pteropus vampyrus ay nanganganib sa AMWS dahil hinuhuli sila ng mga tao kahit ito ay pinagbabawal ng Wildlife Act. Nagsagawa kami ng semi-structured na panayam mula Setyembre, 2017 hanggang Enero, 2018 kasama ang 240 na mga mangangaso mula sa sampung nayon upang malaman ang pang sosyolohiya, pang ekonomiko at pangkultura na mga katangian ng mga mangangaso pati ang kanilang kaalaman at pang unawa sa Wildlife Act, pangangalaga at proteksyon sa nasabing paniki, pagpapatupad ng batas, pagmamanman, mga impormasyon tungkol sa kanilang panghuhuli ng paniki at mga kadahilanan sa panghuhuli. Ipinapakita sa resulta na ang pagsasaka at pangingisda ay ang pinakakaraniwang pangkabuhayan ng mga mangangaso. Karamihan sa mga mangagaso ay nakamit ang edukasyon sa antas ng elementarya (42.9\%), at nabibilang sa isang sambahayan na mayroong 4-6 na miyembro (55.5\%), madalas na may isang miyembro lamang na mayroon kunting kita sa araw-araw (80.7\%). Ang taunang pagbaha ay ang pangunahing hadlang sa ekonomiya ng mga mangangaso. Mga katutubong Manobo ang karamihan sa mga mangangaso (62.9\%) at karamihan din sa kanila ay hindi naniniwala sa pag-iwas sa mga taboo species (85.4\%). Karamihan sa mga mangangaso ay walang kamalayan sa Wildlife Act (62.9\%) at hindi alam ang pagkakaiba ng nanganganib at hind nanganganib na species ng paniki (86.3\%). Ang pagmamanman $n g$ mga bantay-gubat at bantay-lawa at mga tagapagpatupad ng batas ng gobyerno ay napag-alamang hindi regular (mas mababa pa sa isang beses kada buwan) at walang ni isa man lang na mangangaso ang nakitang nahuli o nakulong sa AMWS sa taong $2017-2018$. Ang mga saranggola na may mga kawit (55\%) at baril (31.7\%) ay kadalasang ginagamit sa panghuhuli ng mga paniki na P. vampyrus. Karamihan sa mga mangangaso ay nanghuhuli ng paniki upang may makakain (83.3\%). Napag-alaman din sa pag-aaral na ito na ang mababang pang-araw araw na kita at kakulangan sa pakikipag ugnayan sa konserbasyon ang posibleng dahilan sa mas madalas na pangangaso at mas maraming huli na paniki. Samakatuwid, mas makatwiran at makatotohanang isaalangalang ang mga science-based quotas sa pangangaso sa AMWS kung saan naninirahan ang mga mahihirap na katutubo. Ang pagpapabuti at pagpapatupad ng mga batas na may kinalaman sa proteksyon sa mga buhay ilang sa AMWS ay dapat nakabatay sa masusing pag-aaral upang mapanatili ang balanse ng pangangalaga sa kalikasan at kapakanan ng mga tao lalong lalo na ang mga mahihirap na katutubo. Ang positibong pagbabago sa pag-uugali at ang mas mabisa na pagbabawal sa pangangaso at pagbibinta ng mga paniki ay nangangailangan ng kumbinasyon ng mabisang mga kampanya at edukasyon, pakikipag-ugnayan ng mga katutubo sa konserbasyon, mas mahusay na pagpapatupad $\mathrm{ng}$ quota sa panghuhuli ng paniki at napapanatiling mga programa sa pangkabuhayan. Ang regular na pag-aaral sa populasyon ng mga $P$. vampyrus at iba pang uri ng mga paniki ay mahalaga din upang silay mas lalo pang mapangalagaan ng wasto at hindi tuluyang mauubos.

Author details: DR. SHerRYL L. PAZ is an Associate Professor in the College of Forestry and Environmental Science of Caraga State University. She is currently the chairperson of the Environmental Science Department and the Division Head of Conservation of Mining Biodiversity and its Natural Environment under MinRes of CSU. She graduated PhD in Environmental Science from the University of the Philippines Los Baños (UPLB). Her research interests include terrestrial wildlife conservation and terrestrial wildlife ecology. DR. JUAN CARLOS T. GONZALEZ is the director of UPLB Museum of Natural History and currently professor 11 of Zoology at the Animal Biology Division of the Institute of Biological Sciences, College of Arts and Sciences, UPLB. JC's research interests include the following: ornithology, wildlife biology, conservation biology, vertebrate systematics, phylogeography, tropical evolutionary ecology, and ethno-ornithology.

Author contributions: SLP and JCTG conceptualized and designed the research. SLP performed the surveys and field work activities and analysed the data. Both authors wrote the paper, reviewed, edited, and approved the submission of the final paper. 

Dr. Albert G. Orr, Griffith University, Nathan, Australia

Dr. Sameer Padhye, Katholieke Universiteit Leuven, Belgium

Dr. Nancy van der Poorten, Toronto, Canada

Dr. Kareen Schnabel, NIWA, Wellington, New Zealand

Dr. R.M. Sharma, (Retd.) Scientist, Zoological Survey of India, Pune, India

Dr. Manju Siliwal, WILD, Coimbatore, Tamil Nadu, India

Dr. G.P. Sinha, Botanical Survey of India, Allahabad, India

Dr. K.A. Subramanian, Zoological Survey of India, New Alipore, Kolkata, India

Dr. P.M. Sureshan, Zoological Survey of India, Kozhikode, Kerala, India

Dr. R. Varatharajan, Manipur University, Imphal, Manipur, India

Dr. Eduard Vives, Museu de Ciències Naturals de Barcelona, Terrassa, Spain

Dr. James Young, Hong Kong Lepidopterists' Society, Hong Kong

Dr. R. Sundararaj, Institute of Wood Science \& Technology, Bengaluru, India

Dr. M. Nithyanandan, Environmental Department, La Ala Al Kuwait Real Estate. Co. K.S.C., Kuwait

Dr. Himender Bharti, Punjabi University, Punjab, India

Mr. Purnendu Roy, London, UK

Dr. Saito Motoki, The Butterfly Society of Japan, Tokyo, Japan

Dr. Sanjay Sondhi, TITLI TRUST, Kalpavriksh, Dehradun, India

Dr. Nguyen Thi Phuong Lien, Vietnam Academy of Science and Technology, Hanoi, Vietnam

Dr. Nitin Kulkarni, Tropical Research Institute, Jabalpur, India

Dr. Robin Wen Jiang Ngiam, National Parks Board, Singapore

Dr. Lional Monod, Natural History Museum of Geneva, Genève, Switzerland.

Dr. Asheesh Shivam, Nehru Gram Bharti University, Allahabad, India

Dr. Rosana Moreira da Rocha, Universidade Federal do Paraná, Curitiba, Brasil

Dr. Kurt R. Arnold, North Dakota State University, Saxony, Germany

Dr. James M. Carpenter, American Museum of Natural History, New York, USA

Dr. David M. Claborn, Missouri State University, Springfield, USA

Dr. Kareen Schnabel, Marine Biologist, Wellington, New Zealand

Dr. Amazonas Chagas Júnior, Universidade Federal de Mato Grosso, Cuiabá, Brasil

Mr. Monsoon Jyoti Gogoi, Assam University, Silchar, Assam, India

Dr. Heo Chong Chin, Universiti Teknologi MARA (UiTM), Selangor, Malaysia

Dr. R.J. Shiel, University of Adelaide, SA 5005, Australia

Dr. Siddharth Kulkarni, The George Washington University, Washington, USA

Dr. Priyadarsanan Dharma Rajan, ATREE, Bengaluru, India

Dr. Phil Alderslade, CSIRO Marine And Atmospheric Research, Hobart, Australia

Dr. John E.N. Veron, Coral Reef Research, Townsville, Australia

Dr. Daniel Whitmore, State Museum of Natural History Stuttgart, Rosenstein, Germany.

Dr. Yu-Feng Hsu, National Taiwan Normal University, Taipei City, Taiwan

Dr. Keith V. Wolfe, Antioch, California, USA

Dr. Siddharth Kulkarni, The Hormiga Lab, The George Washington University, Washington,

D.C., USA

Dr. Tomas Ditrich, Faculty of Education, University of South Bohemia in Ceske

Budejovice, Czech Republic

Dr. Mihaly Foldvari, Natural History Museum, University of Oslo, Norway

Dr. V.P. Uniyal, Wildlife Institute of India, Dehradun, Uttarakhand 248001, India

Dr. John T.D. Caleb, Zoological Survey of India, Kolkata, West Bengal, India

Dr. Priyadarsanan Dharma Rajan, Ashoka Trust for Research in Ecology and the Environment (ATREE), Royal Enclave, Bangalore, Karnataka, India

\section{Fishes}

Dr. Neelesh Dahanukar, IISER, Pune, Maharashtra, India

Dr. Topiltzin Contreras MacBeath, Universidad Autónoma del estado de Morelos, México

Dr. Heok Hee Ng, National University of Singapore, Science Drive, Singapore

Dr. Rajeev Raghavan, St. Albert's College, Kochi, Kerala, India

Dr. Robert D. Sluka, Chiltern Gateway Project, A Rocha UK, Southall, Middlesex, UK

Dr. E. Vivekanandan, Central Marine Fisheries Research Institute, Chennai, India

Dr. Davor Zanella, University of Zagreb, Zagreb, Croatia

Dr. A. Biju Kumar, University of Kerala, Thiruvananthapuram, Kerala, India

Dr. Akhilesh K.V., ICAR-Central Marine Fisheries Research Institute, Mumbai Research

Centre, Mumbai, Maharashtra, India

Dr. J.A. Johnson, Wildlife Institute of India, Dehradun, Uttarakhand, India

\section{Amphibians}

Dr. Sushil K. Dutta, Indian Institute of Science, Bengaluru, Karnataka, India

Dr. Annemarie Ohler, Muséum national d'Histoire naturelle, Paris, France

\section{Reptiles}

Dr. Gernot Vogel, Heidelberg, Germany

Dr. Raju Vyas, Vadodara, Gujarat, India

Dr. Pritpal S. Soorae, Environment Agency, Abu Dubai, UAE.

Prof. Dr. Wayne J. Fuller, Near East University, Mersin, Turkey

Prof. Chandrashekher U. Rivonker, Goa University, Taleigao Plateau, Goa. India

Dr. S.R. Ganesh, Chennai Snake Park, Chennai, Tamil Nadu, India

Dr. Himansu Sekhar Das, Terrestrial \& Marine Biodiversity, Abu Dhabi, UAE
Birds

Dr. Hem Sagar Baral, Charles Sturt University, NSW Australia

Dr. Chris Bowden, Royal Society for the Protection of Birds, Sandy, UK

Dr. Priya Davidar, Pondicherry University, Kalapet, Puducherry, India

Dr. J.W. Duckworth, IUCN SSC, Bath, UK

Dr. Rajah Jayapal, SACON, Coimbatore, Tamil Nadu, India

Dr. Rajiv S. Kalsi, M.L.N. College, Yamuna Nagar, Haryana, India

Dr. V. Santharam, Rishi Valley Education Centre, Chittoor Dt., Andhra Pradesh, India

Dr. S. Balachandran, Bombay Natural History Society, Mumbai, India

Mr. J. Praveen, Bengaluru, India

Dr. C. Srinivasulu, Osmania University, Hyderabad, India

Dr. K.S. Gopi Sundar, International Crane Foundation, Baraboo, USA

Dr. Gombobaatar Sundev, Professor of Ornithology, Ulaanbaatar, Mongolia

Prof. Reuven Yosef, International Birding \& Research Centre, Eilat, Israel

Dr. Taej Mundkur, Wetlands International, Wageningen, The Netherlands

Dr. Carol Inskipp, Bishop Auckland Co., Durham, UK

Dr. Tim Inskipp, Bishop Auckland Co, Durham, UK

Dr. V. Gokula, National College, Tiruchirappalli, Tamil Nadu, India

Dr. Arkady Lelej, Russian Academy of Sciences, Vladivostok, Russia

Dr. Simon Dowell, Science Director, Chester Zoo, UK

Dr. Mário Gabriel Santiago dos Santos, Universidade de Trás-os-Montes e Alto Douro,

Quinta de Prados, Vila Real, Portugal

Dr. Grant Connette, Smithsonian Institution, Royal, VA, USA

Dr. M. Zafar-ul Islam, Prince Saud Al Faisal Wildlife Research Center, Taif, Saudi Arabia

Mammals

Dr. Giovanni Amori, CNR - Institute of Ecosystem Studies, Rome, Italy

Dr. Anwaruddin Chowdhury, Guwahati, India

Dr. David Mallon, Zoological Society of London, UK

Dr. Shomita Mukherjee, SACON, Coimbatore, Tamil Nadu, India

Dr. Angie Appel, Wild Cat Network, Germany

Dr. P.O. Nameer, Kerala Agricultural University, Thrissur, Kerala, India

Dr. Ian Redmond, UNEP Convention on Migratory Species, Lansdown, UK

Dr. Heidi S. Riddle, Riddle's Elephant and Wildlife Sanctuary, Arkansas, USA

Dr. Karin Schwartz, George Mason University, Fairfax, Virginia.

Dr. Lala A.K. Singh, Bhubaneswar, Orissa, India

Dr. Mewa Singh, Mysore University, Mysore, India

Dr. Paul Racey, University of Exeter, Devon, UK

Dr. Honnavalli N. Kumara, SACON, Anaikatty P.O., Coimbatore, Tamil Nadu, India

Dr. Nishith Dharaiya, HNG University, Patan, Gujarat, India

Dr. Spartaco Gippoliti, Socio Onorario Società Italiana per la Storia della Fauna "Giuseppe

Altobello", Rome, Italy

Dr. Justus Joshua, Green Future Foundation, Tiruchirapalli, Tamil Nadu, India

Dr. H. Raghuram, The American College, Madurai, Tamil Nadu, India

Dr. Paul Bates, Harison Institute, Kent, UK

Dr. Jim Sanderson, Small Wild Cat Conservation Foundation, Hartford, USA

Dr. Dan Challender, University of Kent, Canterbury, UK

Dr. David Mallon, Manchester Metropolitan University, Derbyshire, UK

Dr. Brian L. Cypher, California State University-Stanislaus, Bakersfield, CA

Dr. S.S. Talmale, Zoological Survey of India, Pune, Maharashtra, India

Prof. Karan Bahadur Shah, Budhanilakantha Municipality, Kathmandu, Nepal

Dr. Susan Cheyne, Borneo Nature Foundation International, Palangkaraja, Indonesia

Dr. Hemanta Kafley, Wildlife Sciences, Tarleton State University, Texas, USA

\section{Other Disciplines}

Dr. Aniruddha Belsare, Columbia MO 65203, USA (Veterinary)

Dr. Mandar S. Paingankar, University of Pune, Pune, Maharashtra, India (Molecular)

Dr. Jack Tordoff, Critical Ecosystem Partnership Fund, Arlington, USA (Communities)

Dr. Ulrike Streicher, University of Oregon, Eugene, USA (Veterinary)

Dr. Hari Balasubramanian, EcoAdvisors, Nova Scotia, Canada (Communities)

Dr. Rayanna Hellem Santos Bezerra, Universidade Federal de Sergipe, São Cristóvão, Brazil

Dr. Jamie R. Wood, Landcare Research, Canterbury, New Zealand

Dr. Wendy Collinson-Jonker, Endangered Wildlife Trust, Gauteng, South Africa

Dr. Rajeshkumar G. Jani, Anand Agricultural University, Anand, Gujarat, India

Dr. O.N. Tiwari, Senior Scientist, ICAR-Indian Agricultural Research Institute (IARI), New

Delhi, India

Dr. L.D. Singla, Guru Angad Dev Veterinary and Animal Sciences University, Ludhiana, India

Dr. Rupika S. Rajakaruna, University of Peradeniya, Peradeniya, Sri Lanka

Dr. Bahar Baviskar, Wild-CER, Nagpur, Maharashtra 440013, India

Reviewers 2018-2020

Due to pausity of space, the list of reviewers for 2018-2020 is available online.
The opinions expressed by the authors do not reflect the views of the Journal of Threatened Taxa, Wildlife Information Liaison Development Society, Zoo Outreach Organization, or any of the partners. The journal, the publisher, the host, and the partners are not responsible for the accuracy of the political boundaries shown in the maps by the authors.

\footnotetext{
Print copies of the Journal are available at cost. Write to:

The Managing Editor, JoTT,

c/o Wildlife Information Liaison Development Society,

No. 12, Thiruvannamalai Nagar, Saravanampatti - Kalapatti Road,

Saravanampatti, Coimbatore, Tamil Nadu 641035, India

ravi@threatenedtaxa.org
} 


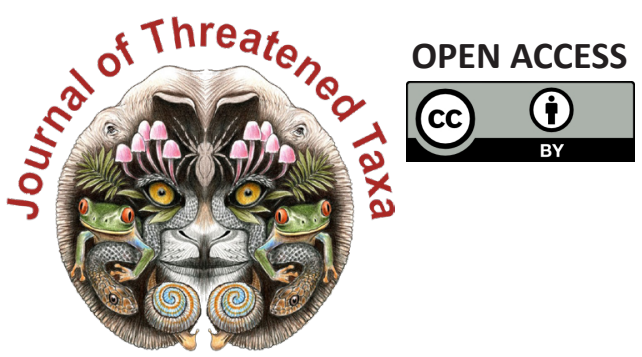

www.threatenedtaxa.org

The Journal of Threatened Taxa (JoTT) is dedicated to building evidence for conservation globally by publishing peer-reviewed articles online every month at a reasonably rapid rate at www.threatenedtaxa.org. All articles published in JoTT are registered under Creative Commons Attribution 4.0 International License unless otherwise mentioned. JoTT allows allows unrestricted use, reproduction, and distribution of articles in any medium by providing adequate credit to the author(s) and the source of publication.

\section{ISSN $0974-7907$ (Online) | ISSN $0974-7893$ (Print)}

\section{September 2021 | Vol. 13 | No. 11 | Pages: 19431-19674 Date of Publication: 26 September 2021 (Online \& Print) DOI: 10.11609/jott.2021.13.11.19431-19674}

Articles

Understanding human-flying fox interactions in the Agusan Marsh Wildlife Sanctuary as basis for conservation policy interventions

- Sherryl L. Paz \& Juan Carlos T. Gonzalez, Pp. 19431-19447

Argentinian odonates (dragonflies and damselflies): current and future distribution and discussion of their conservation

- A. Nava-Bolaños, D.E. Vrech, A.V. Peretti \& A. Córdoba-Aguilar, Pp. 19448-19465

\section{Communications}

The diel activity pattern of small carnivores of Western Ghats, India: a case study at Nelliampathies in Kerala, India

- Devika Sanghamithra \& P.O. Nameer, Pp. 19466-19474

Distribution and threats to Smooth-Coated Otters Lutrogale perspicillata (Mammalia: Carnivora: Mustelidae) in Shuklaphanta National Park, Nepal

- Gopi Krishna Joshi, Rajeev Joshi \& Bishow Poudel, Pp. 19475-19483

Wildlife hunting practices of the Santal and Oraon communities in Rajshahi, Bangladesh - Azizul Islam Barkat, Fahmida Tasnim Liza, Sumaiya Akter, Ashikur Rahman Shome \& M. Fazle Rabbe, Pp. 19484-19491

Ethnozoological use of primates in northeastern India

- Deborah Daolagupu, Nazimur Rahman Talukdar \& Parthankar Choudhury, Pp. 19492-19499

Factors influencing the flush response and flight initiation distance of three owl species in the Andaman Islands

- Shanmugavel Sureshmarimuthu, Santhanakrishnan Babu, Honnavalli Nagaraj Kumara \& Nagaraj Rajeshkumar, Pp. 19500-19508

Birds of Barandabhar Corridor Forest, Chitwan, Nepal

- Saneer Lamichhane, Babu Ram Lamichhane, Kapil Pokharel, Pramod Raj Regmi, Tulasi Prasad Dahal, Santosh Bhattarai, Chiranjibi Prasad Pokheral, Pabitra Gotame,

Trishna Rayamajhi, Ram Chandra Kandel \& Aashish Gurung, Pp. 19509-19526

On some additions to the amphibians of Gunung Inas Forest Reserve, Kedah,

Peninsular Malaysia

- Shahriza Shahrudin, Pp. 19527-19539

Reviews

A review of research on the distribution, ecology, behaviour, and conservation of the Slender Loris Loris lydekkerianus (Mammalia: Primates: Lorisidae) in India

- Mewa Singh, Mridula Singh, Honnavalli N. Kumara, Shanthala Kumar, Smitha D. Gnanaolivu \& Ramamoorthy Sasi, Pp. 19540-19552

Bivalves (Mollusca: Bivalvia) in Malaysian Borneo: status and threats

- Abdulla-Al-Asif, Hadi Hamli, Abu Hena Mustafa Kamal, Mohd Hanafi Idris, Geoffery James Gerusu, Johan Ismail \& Muyassar H. Abualreesh, Pp. 19553-19565

Disentangling earthworm taxonomic stumbling blocks using molecular markers

- Azhar Rashid Lone, Samrendra Singh Thakur, Nalini Tiwari, Olusola B. Sokefun \&

Shweta Yadav, Pp. 19566-19579

A reference of identification keys to plant-parasitic nematodes (Nematoda: Tylenchida) Tylenchomorpha)

- Reza Ghaderi, Manouchehr Hosseinvand \& Ali Eskandari, Pp. 19580-19602

Short Communications

Catalogue of herpetological specimens from Meghalaya, India at the Salim Ali Centre for Ornithology and Natural History

-S.R. Chandramouli, R.S. Naveen, S. Sureshmarimuthu, S. Babu, P.V. Karunakaran \&

Honnavalli N. Kumara, Pp. 19603-19610
A preliminary assessment of odonate diversity along the river Tirthan, Great Himalayan National Park Conservation Area, India with reference to the impact of climate change - Amar Paul Singh, Kritish De, Virendra Prasad Uniyal \& Sambandam Sathyakumar, Pp. 19611-19615

A checklist of orthopteran fauna (Insecta: Orthoptera) with some new records in the cold arid region of Ladakh, India

- M. Ali, M. Kamil Usmani, Hira Naz, Tajamul Hassan Baba \& Mohsin Ali, Pp. 19616-19625

New distribution records of two Begonias to the flora of Bhutan

- Phub Gyeltshen \& Sherab Jamtsho, Pp. 19626-19631

Rediscovery of Aponogeton lakhonensis A. Camus (Aponogetonaceae): a long-lost aquatic plant of India

- Debolina Dey, Shrirang Ramchandra Yadav \& Nilakshee Devi, Pp. 19632-19635

Glyphochloa acuminata (Hack.) Clayton var. laevis (Poaceae): a new variety from central Western Ghats of Karnataka, India

- H.U. Abhijit \& Y.L. Krishnamurthy, Pp. 19636-19639

A cytomorphological investigation of three species of the genus Sonchus L. (Asterales: Asteraceae) from Punjab, India

- M.C. Sidhu \& Rai Singh, Pp. 19640-19644

Dryopteris lunanensis (Dryopteridaceae) - an addition to the pteridophytic diversity of India

- Chhandam Chanda, Christopher Roy Fraser-Jenkins \& Vineet Kumar Rawat, Pp. 1964519648

Notes

First record of Spotted Linsang Prionodon pardicolor (Mammalia: Carnivora:

Prionodontidae) with photographic evidence in Meghalaya, India

- Papori Khatonier \& Adrian Wansaindor Lyngdoh, Pp. 19649-19651

First record of the Eastern Cat Snake Boiga gocool (Gray, 1835) (Squamata: Colubridae) from Tripura, India

- Sumit Nath, Biswajit Singh, Chiranjib Debnath \& Joydeb Majumder, Pp. 19652-19656

First record of the genus Tibetanja (Lepidoptera: Eupterotidae: Janinae) from India - Alka Vaidya \& H. Sankararaman, Pp. 19657-19659

Austroborus cordillerae (Mollusca: Gastropoda) from central Argentina: a rare, little-known land snail

- Sandra Gordillo, Pp. 19660-19662

Intestinal coccidiosis (Apicomplexa: Eimeriidae) in a Himalayan Griffon Vulture Gyps himalayensis

- Vimalraj Padayatchiar Govindan, Parag Madhukar Dhakate \& Ayush Uniyal, Pp. 1966319664

Two new additions to the orchid flora of Assam, India

- Sanswrang Basumatary, Sanjib Baruah \& Lal Ji Singh, Pp. 19665-19670

Wildlife art and illustration - combining black and white ink drawings with colour: some experiments in Auroville, India

- M. Eric Ramanujam \& Joss Brooks, Pp. 19671-19674
Publisher \& Host

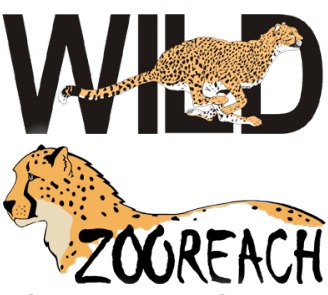

